\title{
Osteoporosis in Premenopausal Women: A Clinical Narrative Review by the ECTS and the IOF
}

\author{
Jessica Pepe, ${ }^{1}$ Jean-Jacques Body, ${ }^{2}$ Peyman Hadji, ${ }^{3}$ Eugene McCloskey, ${ }^{4}$ \\ Christian Meier, ${ }^{5}$ Barbara Obermayer-Pietsch, ${ }^{6}$ Andrea Palermo, ${ }^{7}$ Elena Tsourdi, ${ }^{8,9}$ \\ M.Carola Zillikens, ${ }^{10}$ Bente Langdahl, ${ }^{11, *}$ and Serge Ferrari ${ }^{12, *}$ \\ ${ }^{1}$ Department of Clinical, Internal, Anesthesiology and Cardiovascular Sciences, "Sapienza" University \\ of Rome, Italy; 'Department of Medicine, CHU Brugmann, Université Libre de Bruxelles, Brussels, \\ Belgium; ${ }^{3}$ Frankfurt Center of Bone Health, Frankfurt, Germany and Philipps-University of Marburg, \\ Marburg, Germany; ${ }^{4}$ Centre for Integrated Research in Musculoskleetal Ageing, Mellanby Centre for \\ Bone Research, Department of Oncology and Metabolism, University of Sheffield, Sheffield, UK; ${ }^{5}$ Division \\ of Endocrinology, Diabetology and Metabolism, University Hospital and University of Basel, Basel, \\ Switzerland; ${ }^{6}$ Division of Endocrinology and Diabetology, Department of Internal Medicine, Medical \\ University of Graz, Graz, Austria; ${ }^{7}$ Unit of Endocrinology and Diabetes, Campus Bio-Medico University, \\ Rome, Italy; ${ }^{8}$ Department of Medicine III, Technische Universität Dresden Medical Center, Dresden, \\ Germany ${ }^{9}$ Center for Healthy Aging, Technische Universität Dresden Medical Center, Dresden, Germany; \\ ${ }^{10}$ Bone Center, Department of Internal Medicine, Erasmus University Medical Centre, Rotterdam, The \\ Netherlands; ${ }^{11}$ Department of Endocrinology and Internal Medicine, Aarhus University Hospital, Aarhus, \\ Denmark; ${ }^{12}$ Service of Bone Diseases, Geneva University Hospital and Faculty of Medicine, Geneva, \\ Switzerland
}

ORCiD number: 0000-0002-3088-0673 (J. Pepe); 0000-0002-9582-1906 (E. Tsourdi).

Context: Consensus regarding diagnosis and management of osteoporosis in premenopausal women (PW) is still lacking due to few studies carried out in this population.

Design: The European Calcified Tissue Society and the International Osteoporosis Foundation convened a working group to produce an updated review of literature published after 2017 on this topic.

Results: Fragility fractures in PW are rare and mostly due to secondary osteoporosis (ie, in presence of an underlying disease such as hormonal, inflammatory, or digestive disorders). In absence of another disorder, low bone mineral density (BMD) together with fragility fractures qualifies as idiopathic osteoporosis. In contrast, low BMD alone does not necessarily represent osteoporosis in absence of bone microarchitectural abnormalities. BMD increases in PW with osteoporosis when the underlying disease is treated. For example, in celiac disease, an increase of $9 \%$ in radius trabecular volumetric density was achieved after 1 year of gluten-free diet, while anti-tumor necrosis factor alpha improved BMD in PW with inflammatory bowel diseases. In amenorrhea, including anorexia nervosa, appropriately delivered estrogen replacement therapy can also improve BMD. Alternatively, antiresorptive or anabolic therapy has been shown to improve BMD in a variety of conditions, the range of improvement (3\%-16\%) depending on skeletal site and the nature of the secondary cause. No studies were powered to demonstrate fracture reduction. The effects of bisphosphonates in childbearing women have been scantly studied and caution is needed.

ISSN Print 0021-972X ISSN Online 1945-7197

Printed in USA

*These authors contributed equally to this work.

(c) Endocrine Society 2020. All rights reserved. For permissions, please e-mail: journals.

permissions@oup.com

Received 23 March 2020. Accepted 20 May 2020.

First Published Online 26 May 2020

Corrected and Typeset 11 July 2020 
Conclusion: The majority of PW with osteoporosis have an underlying disease. Specific therapy of these diseases, as well as antiresorptive and anabolic drugs, improve BMD, but without evidence of fracture reduction. (J Clin Endocrinol Metab 105: 1-20, 2020)

Key Words: premenopausal women, osteoporosis, fracture, secondary osteoporosis, pregnancy, antiresorptive therapy

$\mathbf{T}$ he epidemiology of osteoporosis and fracture rate in premenopausal women is uncertain. The prevalence of osteoporosis in premenopausal women varies from $0.5 \%$ to $50 \%$ depending on the population studied, the definition of osteoporosis used, and the referral center involved $(1,2)$. A European study in premenopausal women (mean age $34.8 \pm 0.5$ ) from the general population found no subjects with osteoporosis (defined as a T-score $\leq-2.5 \mathrm{SD})$ and $10.6 \%$ with osteopenia (T-score $>-2.5$ and $\leq-1.0 \mathrm{SD}$ ) (3). However such data can be misleading since a low areal bone mineral density (aBMD) alone at a young age may reflect a relatively thinner skeleton, for instance in a constitutionally lean person, but with normal volumetric bone material density (BMD) and no alterations of microstructure (ie, not necessarily more fragile bones). In contrast, in premenopausal women with known causes of secondary osteoporosis, the prevalence of low bone mass (defined as $\mathrm{Z}$-score $\leq-2 \mathrm{SD}$ ) was recently reported as $17.3 \%$ in patients affected by systemic lupus erythematosus (4), $7.3 \%$ in rheumatoid arthritis (5), $44.5 \%$ in Cushing diseases (6), 35\% in HIV (7), and $45 \%$ in cystic fibrosis (8), and these disorders are associated with an increased risk of fragility fractures.

A premenopausal woman with a prior fracture has a $35 \%$ to $75 \%$ higher risk of having a fracture in her postmenopausal years than a premenopausal woman without fracture (9). Therefore, early diagnosis and management may be beneficial, although currently no studies have investigated this strategy with respect to reducing fractures later in life $(10,11)$. Few reviews on osteoporosis in premenopausal women have been published $(1,2,10,12-15)$, with the latest narrative review and guidance paper dating from $2017(16,17)$. The purpose of the present review is to provide an update on literature published after 2017 regarding diagnosis and management of osteoporosis in premenopausal women, excluding children and adolescents.

\section{Search Strategy}

The European Calcified Tissue Society (ECTS) and the International Osteoporosis Foundation (IOF) formed a working group to carry out a comprehensive review of existing literature by means of a search in PubMed for English-language literature published from January 2017 to July 2019 using the following search terms in the title, without exclusion criteria: "premenopausal," "osteoporosis," "fracture," "pregnancy and lactation induced osteoporosis," "secondary osteoporosis," "anorexia/eating disorders," "vitamin D," "bisphosphonates," "teriparatide," "denosumab," and "calcium."

Among the 248 papers identified, we considered as high-quality papers those reporting on randomized controlled trials (RCTs); we also included observational studies, case series, meta-analysis, and reviews if it was clearly stated that premenopausal women were enrolled. At the end, a total of 139 papers were included in this review.

\section{Factors Affecting Peak Bone Mass and Early Fracture Risk}

The BMD of premenopausal women depends primarily on their bone accrual during childhood and adolescence as the final peak bone mass is reached around the age of 20 years, depending on the skeletal site.

Although $40 \%$ to $80 \%$ of the variation in BMD and bone microarchitecture is genetically determined $(18,19)$, a myriad of diseases and lifestyle factors, even from very early life (20), may influence physiological bone accrual resulting in a lower bone mass in adulthood, as recently reviewed (21).

Lean body mass is a significant predictor of aBMD at all skeletal sites, accounting for $7 \%$ to $26 \%$ of the variance $(P=0.043-0.001)$ (22), after adjusting for age, and bone-specific physical activity. The association between lean mass and bone accrual might also be due to other factors, such as nutrition, hormones, and genetic factors that have independent effects on muscle and bone. Moreover, muscle power has been shown to be a positive determinant of femoral neck (FN) and total hip $\mathrm{BMD}, \mathrm{FN}$ cross-sectional area, FN cross-sectional moment of inertia and FN Z-score in 148 women between 18 and 35 years (23). Thus, it can be speculated that exercise, which improves lean mass and muscle power, has a positive effect on peak bone mass accrual, as it has been shown in previous studies (24-27).

Sexual development and function is crucial for bone mass accrual. A recent Canadian cross-sectional, 
population-based study of 499 menstruating women with a BMD measurement after attaining peak bone mass, showed that $18 \%$ of lumbar spine (LS) BMD was attributed to positive contributions of current body mass index (BMI) and height, with negative influences from previous history of amenorrhea and androgen excess. Approximately $20 \%$ of the variation in FN BMD was explained by current BMI and height (positive effect) and age at menarche (negative effect) (28), as also reported previously (29). A specific group of women, who may experience menstrual dysfunction, are those actively involved in sports at the competitive level. When this is accompanied by a low caloric intake and a low bone density, it constitutes the so-called female athlete triad. Components of the triad are interrelated: if one is identified, the others should be actively evaluated as suggested by the 2017 update consensus on issues in female athletes (30).

\section{Oral contraceptives}

Although hormonal contraception during adolescence was considered a controversial issue regarding bone health in the past, the latest meta-analysis, including 1535 adolescents, showed that combined hormonal contraceptives resulted in a weighted mean LS BMD difference of $-0.02 \mathrm{~g} / \mathrm{cm}^{2}(95 \%$ confidence interval $[\mathrm{CI}]-0.05$ to $0.00, P=0.04$ ) compared to nonusers over a 12-month period (31). The same difference in BMD was seen over 24 months. However a recent retrospective case control study including 12970 premenopausal women reported a significant decrease of fracture risk with the use of combined oral contraceptives. The magnitude of the risk reduction was larger with increased duration of combined oral contraceptive use (32). Depot medroxyprogesterone acetate (DMPA) is a safe injectable contraceptive but most users become amenorrheic within 1 year due to suppression of gonadotropin secretion and consecutive inhibition of ovarian estradiol production. In young women (less than 30 years old) with long-term exposure to DMPA ( $\geq 10$ prescriptions), a higher fracture risk was identified (odds ratio [OR] 3.04, $95 \%$ CI 1.36 to 6.81). Similar findings were reported for women in their late reproductive years with past use of DMPA (OR 1.72, $95 \%$ CI 1.13 to 2.63) (33).

\section{Lifestyle habits}

In 2016, the National Osteoporosis Foundation published a position statement on peak bone mass and lifestyle, as lifestyle habits may contribute to $20 \%$ to $40 \%$ of the mean variance of adult peak bone mass. The best available evidence (grade A) exists on the positive effects of calcium intake and physical activity (34). In addition, protein intake has been shown to enhance the effect of physical activity in the young, in particular at weight-bearing sites (35). It should be noted that there are gene-environment interactions in the skeletal response to nutrition and exercise during growth (36). In particular, a model, which takes into account the early influence of vitamin D receptor polymorphisms, calcium intake, and puberty on areal BMD gain, has been proposed to explain the relation between these genotypes and peak bone mass $(37,38)$, but further longitudinal studies are needed to substantiate this hypothesis. Vitamin D sufficiency promotes normal bone mineralization necessary to obtain an optimal peak bone mass. At the age of 16 years, 25 -hydroxyvitamin D $(25(\mathrm{OH})$ D) $\geq 50 \mathrm{nmol} / \mathrm{L}$ has been associated with a higher total body aBMD, with a lower porosity at the radius and with a higher trabecular number at the tibia as shown by high-resolution peripheral quantitative computed tomography (HR-pQCT) (39). However, data from the United Kingdom National Diet and Nutrition Survey showed that $22 \%$ of adolescents aged 11 to 18 years had $25(\mathrm{OH}) \mathrm{D}<25 \mathrm{nmol} / \mathrm{L}(40)$. Measuring $25(\mathrm{OH}) \mathrm{D}$ in this population, during winter season, increased this percentage up to $40 \%$ (40).

The corollary to the major influence of hormonal and lifestyle habits on peak bone mass acquisition is that childhood disorder affecting pubertal maturation, BMI, nutritional intake, or exercise capacity, among others, will likely have long-lasting repercussions on BMD and fracture risk. A good example is type 1 diabetes mellitus, which is usually diagnosed at a young age, whereby several alterations detrimental to bone health, such as glucose toxicity and deficit in the insulin/insulin-like growth factor 1 axis, lead to a lifelong fracture risk approximately 6 -fold higher than in the nondiabetic population (41).

\section{Diagnosis}

For postmenopausal women the diagnosis of osteoporosis is based on the World Health Organization operational definition of a dual X-ray absorptiometry (DXA) of bone with a T-score below or equal to -2.5 standard deviation (SD). For subjects younger than 40 years old, the International Society for Clinical Densitometry proposed us BMD Z-scores below or equal to -2 SD (comparison to age and sex matched value) to define low bone mass, which is a value below the expected range for age (42).

The IOF also defines low bone mass in the young as Z-scores below $-2 \mathrm{SD}$, however, only before 20 years 
of age. Thereafter, they kept the same definition as in postmenopausal women, namely, a T-score $\leq-2.5$ SD for individuals older than 20 years and in the absence of delayed puberty (1).

Such BMD threshold differences in the definition of premenopausal osteoporosis may result in confounding epidemiological data in the literature. Nevertheless, vertebral and/or multiple fragility fractures with low BMD are a hallmark of osteoporosis for both societies. Hence, for premenopausal women with low BMD (ie, Z-score $\leq-2 \mathrm{SD}$ or T-score $\leq-2.5 \mathrm{SD}$ ) but without fractures, a diagnosis of low peak bone mass vs osteoporosis may be difficult to ascertain. It is important to remember that the pathophysiology of osteoporosis involves not only a deficit in bone quantity (ie, BMD) but also microarchitectural alterations, which in postmenopausal osteoporosis result from increased bone resorption and imbalanced bone remodeling, whereas in premenopausal women they may also result from disturbances in peak bone mass acquisition. Indeed deficits in bone mass, structure, and strength (stiffness) have ben reported using quantitative computed tomography in younger patients with low bone mass and without fracture, as well as in patients with idiopathic osteoporosis with fractures (43). Further studies are therefore needed to define the utility of specific radiological and/or biochemical tools that may help to differentiate true osteoporosis from physiologically low bone mass in the young.

In practice, several steps are necessary for a correct diagnosis of premenopausal osteoporosis, also taking into consideration that current guidelines are based on postmenopausal osteoporosis and do not generally recommend DXA screening in premenopausal women (44). After a detailed medical history and a DXA measurement, including, if possible, a vertebral fracture assessment, an adapted biochemical evaluation is needed to ascertain causes of secondary osteoporosis, as proposed by IOF in 2012 (1). A genetic evaluation is suggested when there is a strong suspicion of a heritable component based on both family history and/or additional clinical features (syndromes) suggestive of an underlying monogenetic bone disorder (1). In absence of this, a diagnosis of idiopathic osteoporosis can me made.

\section{Identifying Patients at High Fracture Risk}

Once a diagnosis of osteoporosis has been made, the next step is to evaluate fracture risk. Although classical risk factors should be taken into account, it is important to note that the FRAX $^{\circledR}$ algorithm is validated for individuals older than 40 years only. Premenopausal women with recent major fragility fractures (hip, vertebral, proximal humerus, and distal forearm fractures) should be considered at high risk for further fractures in the short to medium term, and further assessment is recommended. For example, in a 6-year follow-up study, approximately $25 \%$ of a cohort of 107 patients affected by pregnancy- and lactation-associated osteoporosis (PLAO) had a new fracture, and among individuals who had a new pregnancy, $20 \%$ sustained a new fracture (45).

Premenopausal women without a fracture often undergo a DXA because of existing risk factors for bone fragility. For example, in the case of celiac disease, a Canadian position statement suggests performing DXA measurement at the time of first diagnosis of the underlying disease, which is often at premenopausal ages (46). In this case, as in most cases of secondary osteoporosis, the fracture risk is not only related to BMD and the classical risk factors, but also to the specific characteristics of the underlying disease and its treatment, as also recently illustrated for diabetes (47). In a small prospective study investigating the performance of bone turnover markers in relation to distal radius fractures in premenopausal women, osteocalcin, propeptide of type I procollagen (PINP), bone alkaline phosphatase, and C-terminal telopeptide of type 1 collagen all showed only moderate prediction (48). Bone turnover markers were evaluated 3 months after the fracture, which may still be influenced by the late phase of fracture healing. On another side, in healthy premenopausal women in the transition to menopause (aged 44-57) followed for 5 years, higher PINP and C-terminal telopeptide concentrations predicted lower BMD, suggesting that bone turnover markers could have potential use in identifying women at higher risk of rapid bone loss (49). Yet another recent study suggests that single bone turnover markers may not be able to identify bone loss for an individual patient (50). As previously mentioned regarding their potential utility in the diagnosis of osteoporosis, there are more sophisticated imaging modalities able to assess bone microarchitecture which might also help in the identification of patients at high fracture risk. Although longitudinal studies on the role of HR-pQCT in predicting fracture risk in premenopausal women are not available, new cross-sectional data warrant attention. Premenopausal women with distal radius fracture and mean age $29.8 \pm 8.0$ years showed no differences in aBMD at the radius, FN and LS when compared to subjects of the same age, race, BMI, caffeine intake, alcohol consumption, and physical activity not having experienced fractures (51). However, HR-pQCT revealed 
impaired trabecular and cortical parameters in women having sustained fractures. The addition of individual trabecular segmentation to HR-pQCT images helped to further identify women with radius fractures. The area under the curve for discriminating patients with fracture from women without fracture was 0.74 for the proportion of axially aligned trabeculae (which is an individual trabecular segmentation parameter at radius), whereas the area under the curve values for classical parameters such as aBMD and trabecular density were lower (51). The same trend was reported for tibia measurements (51). Thus, although HR-pQCT parameters are able to capture a difference in bone microstructure between women with and without fracture, independently of $\mathrm{BMD}$, more sophisticated analyses may be necessary to better characterize premenopausal women at increased risk of fracture.

\section{Causes of Secondary Osteoporosis}

Osteoporosis in premenopausal women is more frequently caused by underlying diseases, with the more recent publications summarized in Table 1 (for a more complete list of diseases associated with secondary osteoporosis, see Ferrari et al (1)). In case series and observational studies, which included both premenopausal women and young men with osteoporosis, the majority of the subjects were found to have a cause of secondary osteoporosis at a range varying from $50 \%$ to $90 \%$ depending on the setting and time of diagnosis (52-54). These include well-known conditions with a negative impact on bone health, such as endocrine, inflammatory, neuromuscular, oncological, hematological, pulmonary, and gastrointestinal disorders that are not specific for premenopausal age, but are often diagnosed before menopause (4-6,55-63). Other causes are HIV infection (7), hyperthyroidism (64), and thyroid stimulating hormone suppressive therapy (65). New data from HR-pQCT studies indicate impaired trabecular and cortical compartments in the majority of these diseases, at times detected earlier than the impairment detected by DXA scan (Table 1). A recent retrospective study, which compared the characteristics of minimal trauma vs high trauma hip fractures in young patients, showed higher comorbidity rates in the former group. In addition, endocrinological and neurological diseases as well as nicotine intake were the most frequent. In particular, the number of patients with chronic endocrinological diseases was significantly higher in the minimal trauma group compared to the high trauma group $(34.9 \%$ vs $0 \%, P=0.04)(66)$.
There is a limited number of heritable diseases with a known mutation causing secondary osteoporosis (67). Some of them are solely characterized by bone fragility, while the majority present with additional organ manifestations. Knowing the exact mutation(s) is of pivotal importance when a specific therapy is available. As an example, loss-of-function mutations in the gene encoding the tissue nonspecific alkaline phosphatase cause hypophosphatasia. The diagnosis is based on low alkaline phosphatase activity in serum and genetic testing that identifies the gene mutations, while bone fragility is present with a clinical heterogeneity due to more than 300 mutations of the gene discovered to date (68). Of interest, enzyme replacement therapy is now available for hypophosphatasia, and gene therapy is currently being investigated (68). However, for some other heritable diseases, the discovery of the exact genetic defect has not led to a specific therapy yet. This applies to osteoporosis-pseudoglioma syndrome, which is a rare autosomal-recessive disorder with significant phenotypic variability caused by loss of function mutations in the gene LRP5 characterized by bone fragility and blindness (69).

\section{Anorexia nervosa}

Anorexia nervosa (AN) is another condition associated with the development of osteoporosis in premenopausal women. The classical picture of an anorexic patient is a combination of psychiatric symptoms and somatic manifestations including low BMD, malnutrition, low body fat, and lean mass. Furthermore significant hormonal changes (hypogonadism/amenorrhea, hypercortisolism, low testosterone levels, and resistance to growth hormone with low insulin growth factor [IGF]-1 levels) leads to a significantly lower BMD and higher fracture risk (70). A recent study applying new criteria for diagnosis of AN demonstrated low BMD in $78 \%$ of patients with the classic form of $\mathrm{AN}$, in $82 \%$ of patients with low BMI without amenorrhea, and in $69 \%$ of patients with atypical AN (normal BMI but psychological symptoms of AN) (71). Thus, the deleterious effects of eating disorders on BMD appear to extend beyond our current knowledge of low BMI and amenorrheainduced detrimental effects on BMD (71). A recent systematic review and meta-analysis showed that AN is associated with an increased likelihood of osteoporosis $(\mathrm{OR}=12.59)$ and fractures $(\mathrm{OR}=1.84)(70)$.

Importantly, a low BMI together with low BMD but without bone fragility or eating disorders, as seen in constitutionally lean subjects, should not be mistaken with AN-related osteoporosis (71). 
Table 1. Diseases associated with osteoporosis in premenopausal women, papers published since 2017

\begin{tabular}{|c|c|c|c|}
\hline Diseases & Patients & Findings Summary & $\operatorname{Re}$ \\
\hline \multicolumn{4}{|l|}{ Rheumatology } \\
\hline \multirow[t]{3}{*}{ SLE } & $\begin{array}{l}N=173, \text { mean age } \\
31 \pm 8 \text { years }\end{array}$ & Prevalence of BMD Z <-2 SD was 17.3\%. & \\
\hline & $\begin{array}{l}N=136, \text { mean age } \\
38.8 \pm 12.9 \text { years }\end{array}$ & $\begin{array}{l}\text { Multivariate linear regression analysis considering age, duration of } \\
\text { disease, BMI, high-dose glucocorticoid use and current dose of } \\
\text { glucocorticoids selected as independent variables, showed that } \\
\text { disease duration was negatively associated with LS and FN BMD. } \\
\text { BMI was positively associated with total hip and FN BMD. }\end{array}$ & \\
\hline & $\begin{array}{l}\mathrm{N}=34274,92.6 \% \text { were } \\
\text { female, mean age } \\
41 \text { years, }\end{array}$ & $\begin{array}{l}\text { Multivariable HR for any fracture in SLE age }<50 \text { compared to } \\
\text { age and sex matched controls was: HR } 2.28(1.90-2.74) ; \text { HR } \\
\text { adjusted for glucocorticoids use } 1.74(1.40-2.15) \text {, HR adjusted for } \\
\text { comorbidities } 1.97(1.61-2.41) \text {. All } P<0.01 .\end{array}$ & \\
\hline \multirow[t]{2}{*}{ RA } & $\begin{array}{l}N=96, \text { mean age } \\
36.9 \pm 5.3 \text { years }\end{array}$ & $\begin{array}{l}\text { Higher rate of osteoporosis in RA patients compared to age matched } \\
\text { controls was found. In RA patients, the prevalence of osteoporosis } \\
\text { at radius was } 9.38 \% \text {, at hip } 6.25 \% \text { and at LS } 7.29 \% \text {. }\end{array}$ & \\
\hline & & $\begin{array}{l}\text { Stepwise linear regression analysis showed that total lean mass was } \\
\text { the best, independent significant predictor of BMD at all different } \\
\text { sites, followed by the score of the disease severity (DAS28) at } \\
\text { femoral sites. }\end{array}$ & \\
\hline \multicolumn{4}{|c|}{ ( } \\
\hline $\begin{array}{r}\text { Cushing's } \\
\text { disease }\end{array}$ & $\begin{array}{l}\mathrm{N}=37,28 \\
\text { premenopausal, mean } \\
\text { age } 30.7 \pm 11.7 \text { years }\end{array}$ & $\begin{array}{l}44.5 \% \text { of patients had osteoporosis, } 35.1 \% \text { had morphometric } \\
\text { vertebral fractures. }\end{array}$ & \\
\hline PHPT & $\begin{array}{l}N=54, \text { mean age } \\
40.5 \pm 6.8 \text { years }\end{array}$ & $\begin{array}{l}18.5 \% \text { of patients had osteoporosis at any site. T-score BMD: at distal } \\
\text { third radius was }-1.1 \pm 1.2 \text {, at } L S 1.7 \pm 1.3 \text {, at FN } 1.5 \pm 1.2 \text {. }\end{array}$ & \\
\hline DM type 1 & $\begin{array}{l}N=35925 \text { (male and } \\
\text { female), mean age } \\
18-50 \text { years }\end{array}$ & $\begin{array}{l}\text { This meta-analysis showed a RR for any fracture of } 1.85(95 \% \mathrm{Cl} \\
1.5-2.3, P<0.001) \text { in diabetic females compared to controls. }\end{array}$ & \\
\hline \multicolumn{4}{|c|}{ Gastroenterology/Malnutrition } \\
\hline Celiac disease & $\begin{array}{l}\mathrm{N}=563 \text { premenopausal } \\
\text { women and men, age } \\
\text { NA }\end{array}$ & $\begin{array}{l}\text { In this meta-analysis, the pooled prevalence of osteoporosis was } \\
14.4 \%(95 \% \mathrm{Cl}: 9-20.5 \%) \text { and osteopenia was 39.6\% (31.1- } \\
48.8 \%) \text { respectively. }\end{array}$ & \\
\hline IBD & $\begin{array}{l}N=59, \text { mean age } \\
23.1 \pm 5.8 \text { years }\end{array}$ & $\begin{array}{l}\text { IBD patients had a nearly } 10 \% \text { lower aBMD at radius, spine } \\
\text { and hip and alterations in trabecular and cortical bone } \\
\text { microarchitecture. Higher disease activity scores had a negative } \\
\text { impact on aBMD and vBMD, as well as microstructure. Prevalent } \\
\text { fractures in IBD were not associated with aBMD (adjusted for } \\
\text { age, sex and height), but with vBMD and with alterations of } \\
\text { trabecular bone microarchitecture. }\end{array}$ & \\
\hline $\begin{array}{l}\text { Anorexia } \\
\text { nervosa }\end{array}$ & $\begin{array}{l}N=25, \text { mean age } \\
27.5 \text { years }(23.8 ; 29.6)\end{array}$ & $\begin{array}{l}\text { Lower bone mass and impaired bone microarchitecture in adult AN } \\
\text { patients, compared to normal weight controls. The impairment } \\
\text { of cortical thickness and estimated failure load were significantly } \\
\text { more pronounced in the weight-bearing tibia, compared to the } \\
\text { radius. }\end{array}$ & \\
\hline \multicolumn{4}{|l|}{ Infectious disease } \\
\hline PLWH & $\begin{array}{l}\mathrm{N}=103, \text { median age } 35 \\
\quad(25-45 \text { years })\end{array}$ & $\begin{array}{l}\text { Osteoporosis was documented in } 35 \% \text { of females with HIV as } \\
\text { compared to } 8 \% \text { of HIV-negative controls }(P<0.001) \text {. BMI was an } \\
\text { independent predictor of osteoporosis, after adjusting for age and } \\
\text { disease duration. }\end{array}$ & \\
\hline \multicolumn{4}{|c|}{ 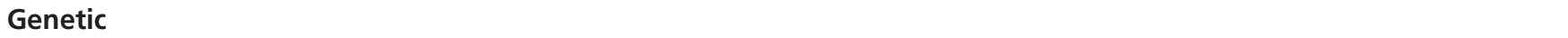 } \\
\hline \multirow[t]{2}{*}{ Cystic fibrosis } & $\begin{array}{l}\mathrm{N}=42 \text { patients }(24 \\
\text { females, mean age } \\
34.0 \pm 8.4 \text { years })\end{array}$ & $\begin{array}{l}\text { A BMD Z score below }-2.0 \text { SD or lower and at least one prevalent } \\
\text { fragility fracture were found in } 22 \text { patients }(52.4 \%) \text { and } 18 \text { patients } \\
(45.2 \%) \text {, respectively. }\end{array}$ & \\
\hline & $\begin{array}{l}N=53, \text { mean age } 27.5 \\
(25.7-29.3)\end{array}$ & $\begin{array}{l}20 \% \text { of patients had osteoporosis at LS (T score }<-2,5 \text { SD), and 35\% } \\
\text { at femoral sites. }\end{array}$ & \\
\hline $\begin{array}{l}\text { Thalassemia } \\
\text { major }\end{array}$ & $\begin{array}{l}\mathrm{N}=82 \text { patients, } \mathrm{N}=39 \\
\text { premenopausal } \\
\text { women, mean age } \\
32 \pm 6 \text { years }\end{array}$ & $\begin{array}{l}15 \text { patients had vertebral fractures, their mean LS BMD Z score } \\
\text { was }-2.66 \text { SD and TBS } 1.173 \text {, both significantly lower than in the } \\
\text { patients without fractures. }\end{array}$ & \\
\hline
\end{tabular}

Abbreviations: BMD, bone mineral density; BMI, body mass index; DM, diabetes mellitus; FN, femoral neck; HR, hazard ratio; IBD, inflammatory bowel disease; LS, lumbar spine; N, number; NA, not available; PHPT, primary hyperparathyroidism; PLWH, people living with HIV; RA, rheumatoid arthritis; Ref, references; SLE, systemic lupus erythematosus; TBS, trabecular bone score. 


\section{Lifestyle and dietary alterations}

Lifestyle habits such as excessive alcohol consumption, as well as heavy smoking, play an important role in the pathogenesis of bone fragility in premenopausal women. In a population of 789 premenopausal women aged 20 to 40 years, the OR for low LS BMD compared to nonsmokers was 1.59 (95\% CI 0.65 to 3.91) and 2.55 (95\% CI 1.12 to 5.82 ) for subjects with tobacco use of less or more than 3 pack-years, respectively (72).

Exclusion of animal meat protein intake (vegetarianism) and even more so strict exclusion of any animal products (veganism) also carry an increased risk of osteoporosis. In a Bayesian meta-analysis, which included 9 studies (2749 individuals; 1880 women with an average age ranging from 20 to 79 years), vegetarians showed a significant BMD reduction amount to $4 \%$ and an increase of $10 \%$ higher in fracture risk compared to nonvegetarians (73). However, in a recent cross-sectional study, which included vegetarians and vegans with a mean age of approximately 30 years, $83 \%$ of whom were female, calcaneus mineral density did not differ between vegetarians and nonvegetarians or between vegans and lacto-ovo vegetarians (74). Of note, the majority of vegetarians followed this diet for less than 5 years, and the authors used heel ultrasound, rather than DXA, which is the standard technique to measure bone density. In this study, protein, calcium, and vitamin D intakes of vegetarians were all lower than the respective intake of subjects whose diets included meat $(P<0.05)$ (74). Hypovitaminosis $\mathrm{D}$, although more frequent in vegetarians, is also an issue in meat-consuming premenopausal women (75), often in association with intestinal malabsorption. Osteomalacia should be differentiated from osteoporosis when a low BMD is reported. It should be noted, that malnutrition can also have a socioeconomical background, in particular in developing countries; a cross-sectional study conducted in among 430 women of reproductive age showed malnutrition in $48.6 \%$ of the subjects (76).

\section{Cancer-related and drug-induced osteoporosis}

There is new evidence regarding the deleterious skeletal effects of drugs used only in women, in particular in the setting of breast cancer (77-80) (Table 2). Hence, adjuvant therapy, including chemotherapy and gonadotropin-releasing hormone $(\mathrm{GnRH})$ analogs can induce secondary amenorrhea and premature menopause. Moreover, tamoxifen, a selective estrogen receptor modulator, which has a protective role on bone in postmenopausal women, acts as an antiestrogen in premenopausal women and has been associated with a $75 \%$ increased risk of fracture in premenopausal patients with breast as compared to healthy controls (hazard ratio [HR] 1.75; 95\% CI 1.25 to 2.48) (77).

In 2018, the Food and Drug Administration approved elagolix, an orally administered nonpeptide GnRH receptor antagonist, for endometriosis associated-pain management. Administered from 6 to a maximum of 12 months, this drug was associated with BMD loss, especially with higher dosage $(81,82)$ (Table 2$)$. Recently, elagolix has been successfully used for uterine bleeding caused by fibroids, and also in this instance its use resulted in decreased bone density which was mitigated when estradiol, $1 \mathrm{mg}$, and norethindrone acetate, $0.5 \mathrm{mg}$, both taken once daily, were added (83).

Regarding cancer-related osteoporosis, both cancer itself, as well as its treatment, may induce bone loss. For example, autologous or allogeneic hematopoietic stem cell transplantation is the treatment of choice for most young patients with malignant hematological diseases; however, hematopoietic stem cell transplantation-related bone loss and increased fracture rate are among the main complications of this life-saving therapeutic intervention (84).

Glucocorticoid-induced osteoporosis in premenopausal women is usually seen in patients with autoimmune/inflammatory disorders and rheumatological diseases, themselves a cause of osteoporosis. Even if glucocorticoids exert multiple negative effects on bone health (85), they are also able to some extent to control the activity of the underlying disease, which in turn may exert some favorable effects on the preservation of bone mass/strength. These aspects have not been adequately investigated in premenopausal women (86), but current management guidelines are discussed in the following text.

\section{Idiopathic Osteoporosis}

Idiopathic osteoporosis is defined as the occurrence of a low trauma fracture in the presence of low BMD (LS and or hip T-score $\leq-2.5 \mathrm{SD}$ ) after excluding causes of secondary osteoporosis (1). The exact mechanisms underlying this disease remain incompletely understood but abnormalities in bone formation have been found on bone biopsies (87). Constitutionally lean subjects with low BMD, which is usually caused by low peak bone mass accrual related to both the genetic constitution, lifestyle, and environmental conditions (1) should not be considered affected by idiopathic osteoporosis, at least not in the absence of fragility fractures.

Examination of bone microstructure using HR-pQCT showed numerous similarities between a group of 23 young patients with idiopathic osteoporosis defined 
Table 2. Drugs specifically used in women and their effects on bone, papers published since 2017

\begin{tabular}{|c|c|c|c|c|}
\hline Drugs & Patients & $\begin{array}{l}\text { Study De- } \\
\text { sign }\end{array}$ & Findings Summary & Ref \\
\hline Tamoxifen & $\begin{array}{l}\mathrm{N}=3634 ; \text { mean } \\
\quad \text { age } 44.1 \pm 5.1 \\
\quad(18-50 \text { years })\end{array}$ & $\begin{array}{l}\text { Retrospective } \\
\text { study }\end{array}$ & $\begin{array}{l}\text { In patients with breast cancer treated with tamoxifen, a } \\
\text { cumulative incidence of fractures was } 6.3 \% \text { compared to a } \\
\text { cumulative incidence of } 3.6 \% \text { in the control group }(P<0.001) \text {. } \\
\text { The risk of fracture was } 75 \% \text { higher for patients taking } \\
\text { tamoxifen than that for healthy controls }(\mathrm{HR} 1.75 ; 95 \% \mathrm{Cl} \\
1.25 \text { to } 2.48) \text {. }\end{array}$ & 77 \\
\hline Tamoxifen & $\begin{array}{l}\mathrm{N}=1761 \\
\text { mean age } \\
43.3 \pm 6.1 \text { years; } \\
\text { age } 41-50 \text { years } \\
(72.8 \%) \text { age } 31- \\
40 \text { years }(22.3 \%) \\
\text { age } 18-30 \text { years } \\
(4.9 \%)\end{array}$ & $\begin{array}{l}\text { Retrospective } \\
\text { cohort }\end{array}$ & $\begin{array}{l}\text { A positive association was found between breast cancer and } \\
\text { fractures, adjusted } \mathrm{HR}=2.39,(P<0.001) \text {. HR was } 2.58 \\
(P<0.001) \text { for women on tamoxifen versus healthy women, } \\
\text { while HR for women without tamoxifen treatment versus } \\
\text { healthy women was not statistically significant. After } 10 \text { years, } \\
\text { women with fractures were } 14.7 \% \text { in the tamoxifen group vs } \\
12.9 \% \text { in the group without tamoxifen. This difference was not } \\
\text { statistically significant. }\end{array}$ & 78 \\
\hline $\begin{array}{l}\text { Tamoxifen } \\
\text { plus ovarian } \\
\text { function } \\
\text { suppression } \\
\text { (OFS) }\end{array}$ & $\begin{array}{l}\mathrm{N}=4690, \text { age } \\
40 \text { years }\end{array}$ & $\begin{array}{l}\text { RCT SOFT } \\
\text { and TEXT } \\
\text { trial } \\
\text { (8 years } \\
\text { follow-up) }\end{array}$ & $\begin{array}{l}\text { Percentage of patients with T-score of less than }-2.5 \text { SD was } \\
3.9 \% \text { in the tamoxifen group, } 7.2 \% \text { in the combined } \\
\text { tamoxifen-ovarian suppression group, and in } 14.8 \% \text { in the } \\
\text { combined exemestane-ovarian suppression group. }\end{array}$ & 79 \\
\hline $\begin{array}{l}\text { Aromatase } \\
\text { inhibitor (Al) } \\
\text { plus OFS }\end{array}$ & $\begin{array}{l}N=27, \text { mean age } \\
43 \text { years (range } \\
30.4 \text { to } 53.7 \text { ) }\end{array}$ & $\begin{array}{l}\text { Cross- } \\
\text { sectional }\end{array}$ & $\begin{array}{l}\text { In patients with early breast cancer treated with OFS + Al for a } \\
\text { median duration of } 17 \text { months, the cortical and trabecular } \\
\text { volumetric BMD, assessed by HR-pQCT, was reduced compared } \\
\text { to healthy age-matched controls. Also matrix mineral density } \\
\text { was } 1.56 \mathrm{SD}(0.90 \text { to } 2.22) \text { lower than controls. }\end{array}$ & 80 \\
\hline Elagolix & $\begin{array}{l}\mathrm{N}=872 \text { in Elaris } \\
\mathrm{EM}-\mathrm{I} \text { trial } \\
\mathrm{N}=817 \text { in Elaris } \\
\text { EM-II trial } \\
\text { Mean age } 31 \text { years } \\
\text { old }\end{array}$ & $\begin{array}{l}\text { Double-blind, } \\
\text { placebo- } \\
\text { controlled } \\
\text { phase } \\
3 \text { trials } \\
\text { (6 months) }\end{array}$ & $\begin{array}{l}\text { In Elaris EM-I, after } 6 \text { months, a decrease of more than } 5 \% \text { in } \\
\text { LS BMD was reported in } 3.8 \% \text { of patients on a low dose of } \\
\text { elagolix, compared to } 20.9 \% \text { of patients in the higher-dose } \\
\text { elagolix group. In Elaris EM-II, the respective percentages were } \\
2.3 \% \text { and } 16.4 \% \text {. }\end{array}$ & 81 \\
\hline Elagolix & $\begin{array}{l}\text { Extension Trial EM- } \\
\quad \text { III and IV } \\
\mathrm{N}=569 \text { women } \\
\text { Mean age } 32 \text { years } \\
\text { old }\end{array}$ & $\begin{array}{l}\text { Double-blind, } \\
\text { placebo } \\
\text { controlled } \\
\text { phase } 3 \text { trials } \\
\text { (12 months) }\end{array}$ & $\begin{array}{l}\text { After } 12 \text { months, in EM-III, the mean percentage age change } \\
\text { from baseline in LS BMD was }-0.63 \% \text { for the low dose (Elaris } \\
\text { EM-IV }-1.10 \% \text { ) and }-3.60 \% \text { for the high dose (Elaris EM-IV } \\
3.91 \% \text { ). None of the patients had a Z-score below }-2.0 \text {. }\end{array}$ & 82 \\
\hline
\end{tabular}

Abbreviations: BMD, bone mineral density; HR, hazard ratio; HR-pQCT, high-resolution peripheral quantitative computed tomography; $\mathrm{N}$, number; $\mathrm{RCT}$, randomized control trial; Ref, references.

as prevalent fragility fractures and low BMD (without mutations in known osteoporosis-causing genes) and a group of 21 age- and sex-matched patients affected by mild to moderate osteogenesis imperfecta (type 1 and type IV). Both groups showed significant reduction in volumetric BMD and alterations in microstructural parameters at the distal radius and tibia compared to healthy controls. The only difference reported between osteogenesis imperfecta patients and patients with idiopathic osteoporosis was regarding geometry of the radius. No other differences were detected in HR-pQCT parameters at the radius and tibia (88).

In an attempt to better characterize idiopathic osteoporosis in young patients, next-generation sequencing was performed to screen for genes previously associated with fracture or low BMD in a cohort of 123 young adults with idiopathic osteoporosis. Novel variants were found in 11 subjects (regarding the following genes: COL1A2, WNT1, PLS3, and DKK1); however, there was no control group. In addition, previously reported osteoporosis-causing variants in the LRP5 gene were found in 22 patients (89). In contrast, $45.5 \%$ of the patients studied carried no genetic variants in the examined genes. LRP5 variants have previously also been associated with idiopathic osteoporosis in men (90).

\section{Pregnancy- and Lactation-Associated Osteoporosis}

During pregnancy and lactation, the changes in calcium metabolism lead to a transient bone loss, mainly at trabecular sites (91). Among the factors involved, parathyroid hormone related protein is secreted into the maternal circulation from the breasts tissue and placenta and reaches its highest concentrations during the third trimester. After lactation, recovery of bone mass and strength normally occurs (92). In the long term, some studies showed that pregnancy and lactation 
have a negative effect on bone health later in life, while other studies did not, as previously reviewed $(92,93)$. Recently, in a study including 16000 women followed for 16 years, parity and lactation were found to have a neutral effect on the long-term development of osteoporosis or fragility fractures (both clinical and morphometric) (94).

Against this background, PLAO is characterized by fragility fractures occurring during pregnancy or lactation, and has been reported in approximately 210 cases in the literature but is much more common in reality $(95,96)$. The precise cause of this rare disorder remains unknown, in particular it remains unclear whether it is entirely caused by pregnancy itself in certain individuals and/or whether pregnancy reveals a status of prior bone fragility. A search for causes of secondary osteoporosis should be undertaken in women suffering a fracture during pregnancy and lactation.

The largest case-control study (102 PLAO subjects) identified various risk factors associated with this condition. Performing fewer sports both before and after puberty, having had dental problems in childhood, and having suffered severe diseases and immobilization during pregnancy were all risk factors significantly more frequent in PLAO subjects than in controls (95). The same risk factors were identified in a retrospective case-control study for transient osteoporosis of the hip during pregnancy, where immobilization during pregnancy was thrice more frequent in patients with transient osteoporosis of the hip compared to the control group (96). The latest and largest bone biopsy study in PLAO women where bone biopsies were performed 12 months postpartum, aimed to assess the baseline state of bone remodeling. Transiliac bone biopsies in these women, showed a low bone turnover state, which was also confirmed by circulating bone turnover markers compared to patients affected by idiopathic osteoporosis, itself already a state of low bone formation (97). This study showed a dissociation between low PINP in PLAO compared to controls, while the concentration of C-terminal telopeptide of type 1 collagen did not significantly differ (97).

These novel findings suggest the possibility of an underlying defect in osteoblast function taking into consideration the lower bone formation reported in PLAO women in the absence of lower osteoblast number (97).

In a small study of 7 PLAO patients, in addition to HR-pQCT, which revealed a reduction of the trabecular and cortical thicknesses, and DXA assessment, which revealed low BMD, a comprehensive genetic analysis was carried out. Using a custom-designed gene panel, a heterozygous missense variant in the
LRP 5 gene was reported in one of the patients, and 2 women were diagnosed with osteogenesis imperfecta caused by heterozygous mutations in the COL1A2 and COL1A1 gene (98).

In summary, PLAO patients appeared to have the same risk factors for osteoporosis as those recognized for the development of postmenopausal osteoporosis and/or a possible osteoblast dysfunction revealed from bone biopsy and genetic analysis. Thus, it might be possible that a pre-existing bone impairment is present before pregnancy and that pregnancy is a trigger for its clinical development. However, further studies are needed to fully understand the exact mechanism beyond PLAO.

\section{Management}

Management of premenopausal osteoporosis is challenging due to a lack of robust evidence of how best to predict and decrease future fracture risk. Only few studies have assessed the effect of medical treatment and all were small-scale (Table 3).

A flow-chart for the overall management of premenopausal women with osteoporosis and fragility fractures is shown in Fig. 1.

\section{Nonpharmacological approaches}

A 2-year RCT, which included 470 premenopausal women, aged 25 to 44 years, showed that educating young women concerning classical osteoporosis risk factors was associated with long-term improvements in osteoporosis preventive behavior. This change in behavior, followed-up for 10 years, led to an approximate $2.4 \%$ attenuation of FN BMD loss in this population (99). This is of particular importance considering that a recent review on the knowledge, beliefs, and practices regarding osteoporosis among young adults revealed their lack of awareness about the disease (100).

Recently, new evidence on the effects of physical activity in premenopausal women has been published $(101,102)$. Forty young women, aged 30 to 45 years and recently diagnosed with osteoporosis, were divided into 4 groups with the following interventions over a period of 10 weeks: training (aerobic-resistance) group plus milk consumption (500 mL daily), only milk consumption, only training and controls. This study showed that there were significant differences in hip and LS BMD in the training plus milk group with higher values compared to training, milk consumers, and control groups (101). However, the small sample size and short duration of intervention limit a clinical translation of these findings. 


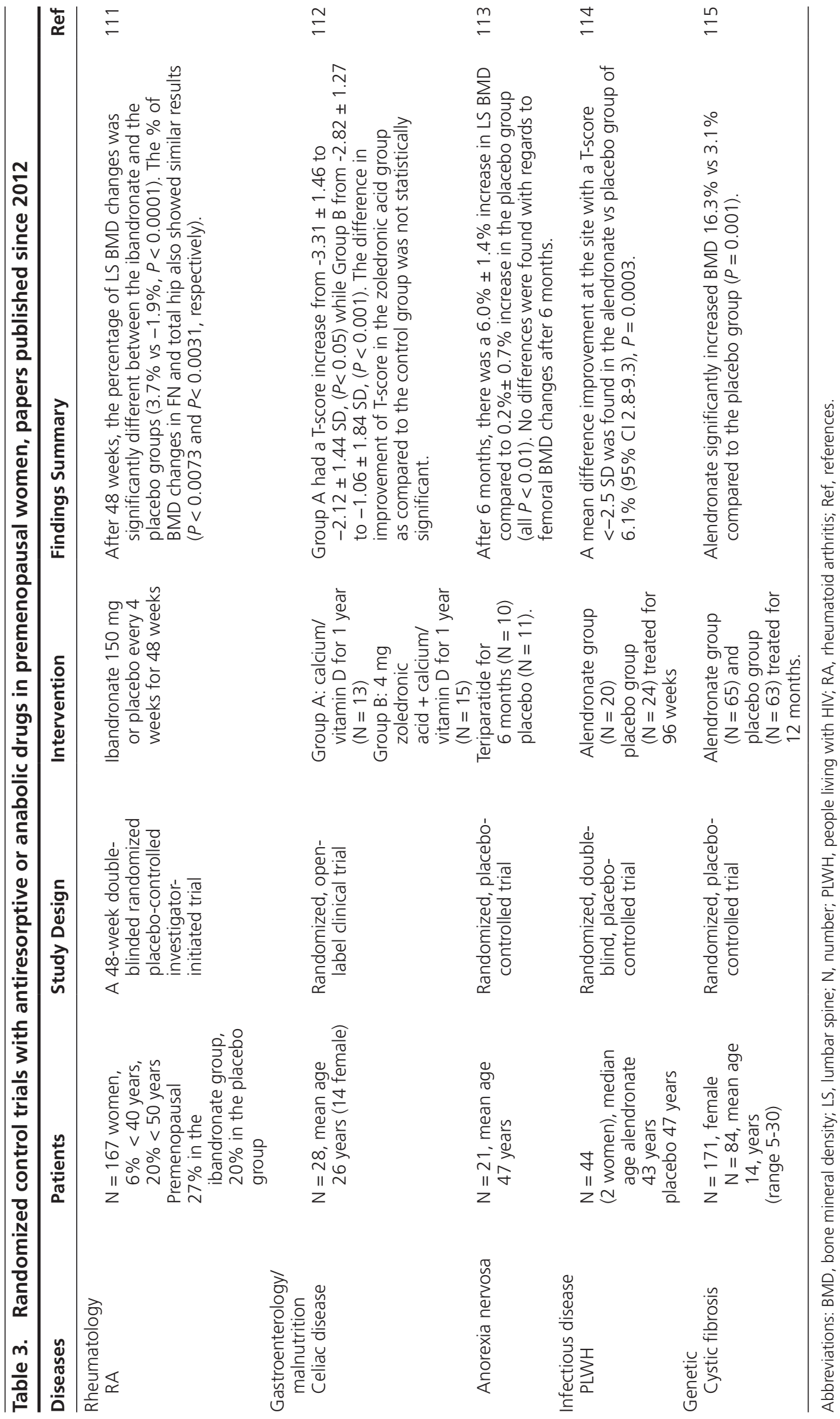




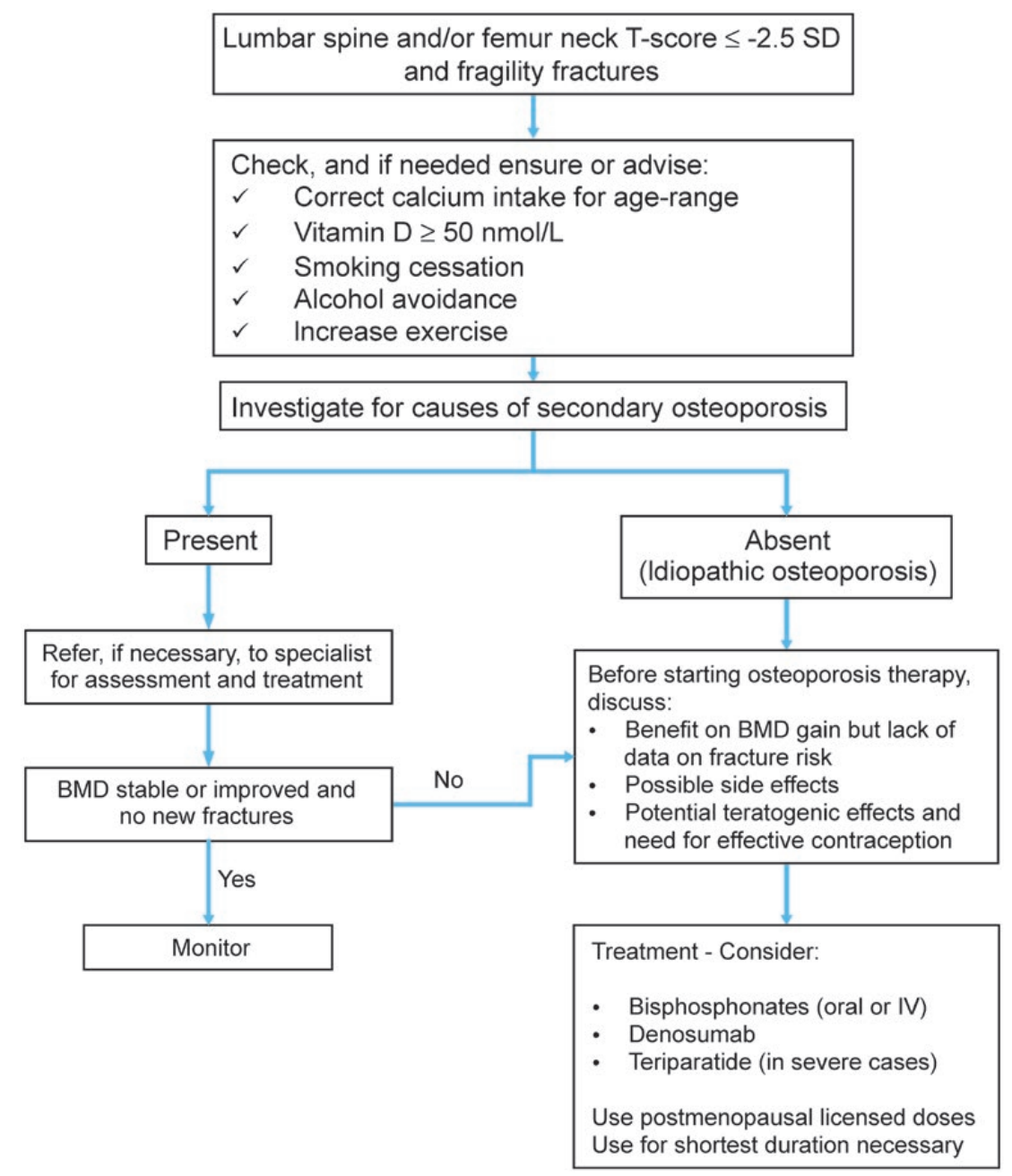

Figure 1. Flow chart on management and pharmacological treatment in premenopausal women with osteoporosis and fragility fracture (age $>20$ years old).

A RCT, including 206 premenopausal women diagnosed with breast cancer before the age of 55 years showed that an exercise intervention with a combination of resistance training and aerobic exercise within 2 years of receiving adjuvant chemotherapy, prevented LS bone loss over a 12-month follow-up (LS BMD $+0.001 \pm 0.005 \mathrm{~g} / \mathrm{cm}^{2}$ treatment group vs $-0.014 \pm 0.005 \mathrm{~g} / \mathrm{cm}^{2}$ control group, $P=0.03$ ) in women who did not suffer loss of lean mass during the study (102).

Although it is strongly advocated to quit smoking and alcohol consumption, no studies have demonstrated its effects on $\mathrm{BMD} /$ fracture risk in premenopausal women.

\section{Pharmacological treatment}

Calcium and vitamin D. In the latest National Osteoporosis Foundation report, 93\% of premenopausal women (aged 19-30 years) had a dietary calcium intake below that suggested in the guidelines (34). When specifically asked about perceived adequate calcium intake, premenopausal women (aged 18-34 years) answered that they were uncertain of what the benefits would be for their own age group but understood the importance for older ages (103). Vitamin D deficiency in premenopausal women was observed in various geographic areas, as recently reported by the latest ECTS position statement on vitamin D (75). Of particular concern, are the specific risk factors of hypovitaminosis $\mathrm{D}$, such as covering of the body for traditional and/or religious reasons (104) and malabsorption syndromes, where higher rates of severe vitamin D insufficiency have been shown (105). Specific randomized trials with different dosages or schemes of calcium or vitamin D supplementation are lacking in this population in order to draw definite conclusions regarding the best treatment strategy. Thus, in clinical practice, guidelines for the supplementation of calcium and vitamin $\mathrm{D}$, with a target level of at least $50 \mathrm{nmol} / \mathrm{L} 25(\mathrm{OH})$ vitamin $\mathrm{D}$ in postmenopausal osteoporosis are usually implemented also for premenopausal patients with osteoporosis (44). 
Antiresorptive and bone-forming therapy. Women at high fracture risk, such as patients with fragility fractures and low BMD, should be treated with bone drugs particularly if the underlying disease is difficult to control; however, fracture risk reduction with both antiresorptive and bone-forming treatment has not been demonstrated for premenopausal women with either secondary or idiopathic osteoporosis. Studies carried out so far usually were small-scale with short followup periods and assessed BMD changes as the primary outcome. Several studies confirm that treatment of the underlying disease improves BMD in PW with secondary osteoporosis (Table 4) (106-110) but may not be sufficient.

Several recent publications, albeit few in the form of randomized trials, have shown improvement in BMD of premenopausal women using these drugs (111-115), as summarized in Table 3. This table also includes RCTs published after 2012, the time when the latest table summarizing treatments was published by IOF (1).

Two systematic reviews were recently published concerning treatment of osteoporosis in men and women affected by cystic fibrosis (116) and by ß-thalassemia (117), and although only a few premenopausal women were included, both reviews concluded that bisphosphonates exerted a positive effect on BMD in these patients, but evidence regarding fracture reduction was lacking.

The latest meta-analysis in patients with inflammatory bowel disease, which included 13 RCTs and 923 male and female patients (age range 30-47 years) demonstrated an improvement in BMD and a fracture reduction following bisphosphonate treatment; however, only 96 premenopausal women received an active bisphosphonate treatment, representing only $10 \%$ of the sample (118).

In patients with $\mathrm{AN}$, weight gain is an important determinant for the recovering of BMD (119) and bisphosphonates are an option for increasing BMD (120). The latest review included 1119 participants, and 10 of the 19 included studies were double-blind RCTs. However, the majority of the studies had a short follow-up period (ranging from 3 to 34 months), and the participants ages ranged from 11 to 37 years; thus, also patients who had not yet reached peak bone mass were included (120). Interestingly, in this review, the authors reported that administration of oral contraceptives did not significantly increase BMD in randomized controlled trials; however, transdermal administration in adolescents was efficient in improving BMD, without data on fracture reduction (120). Another option such as low-dose testosterone did not change BMD but increased lean body mass in a 1-year follow-up study (121).

Glucocorticoid-induced osteoporosis. In 2012 IOF and ECTS published a joint paper on the management of glucocorticoid-induced osteoporosis and considered a premenopausal woman taking oral glucocorticoid for at least 3 months at risk for future fractures if she had a previous fracture (122). Clinical risk factors and the dose of prednisolone should also be taken into account for fracture risk assessment (122).

Furthermore, the latest American College of Rheumatology guidelines published in 2017 considered women $<40$ years of age with a fragility fracture at high risk for future fractures. DXA measurement is recommended for patients at high and moderate risk, but also for patients receiving very high dosages of glucocorticoids or with other known risk factors for osteoporosis (123). Subjects with a hip or spine BMD Z score <-3 $\mathrm{SD}$, or with a rapid bone loss $(\geq 10 \%$ at the hip or spine over 1 year) and who have been treated with glucocorticoids for $\geq 6$ months at a daily dose $\geq 7.5 \mathrm{mg}$ are considered at moderate risk. Low-risk subjects are those treated with glucocorticoids without the previously mentioned conditions (123). We believe that due to the well-known detrimental effects of glucocorticoids, it may be a too conservative approach to not consider patients who have been receiving glucocorticoids for $\geq 6$ months at a daily dose $\geq 7.5 \mathrm{mg}$ with a BMD Z score $<-3 \mathrm{SD}$, or with a rapid bone loss, at high risk for fracture. Until now, long-term follow-up studies designed to distinguish between high and moderate fracture risk in young premenopausal women, in this setting, are missing.

For low-risk patients the American College of Rheumatology recommend the administration of only calcium and vitamin D. For moderate- and high-risk patients, oral bisphosphonates, in view of their safety and cost, are the preferred drugs (123). The IOF-ECTS GIO Guidelines Working Group suggested to start osteoporosis treatment for premenopausal women with fractures, while for women without fracture treatment decision should be based on clinical judgment, due to limited evidences (122).

Cancer-related osteoporosis. In the absence of guidelines for fractures prevention in premenopausal women with breast cancer and hormone ablation therapy, it has been suggested that bisphosphonates should be initiated in women with a $Z$ score less than $-2 \mathrm{SD}$. In women with a $Z$ score equal to or less than -1 SD and a $5 \%$ to $10 \%$ annual decrease in BMD, bisphosphonates are also 


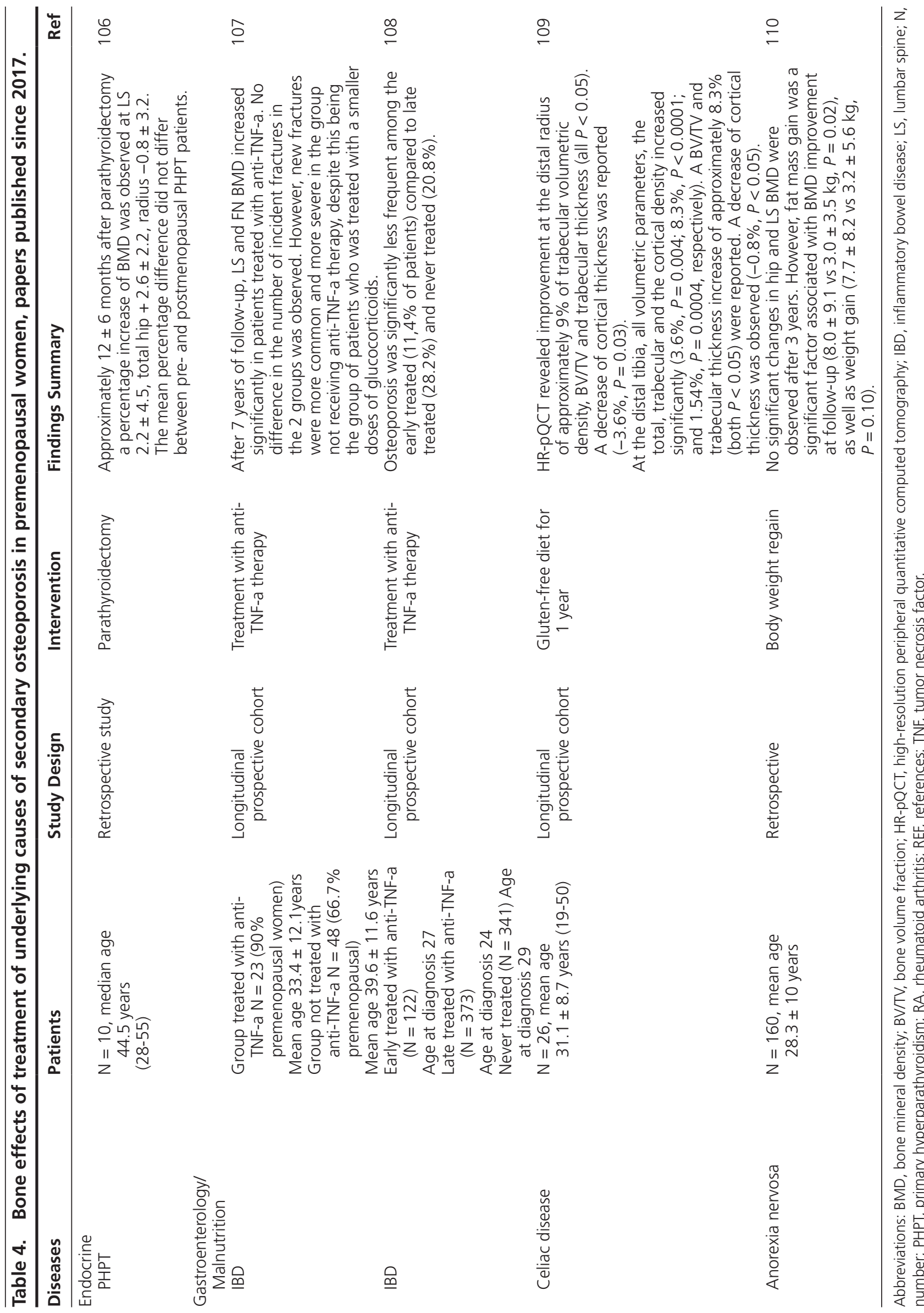


suggested together with calcium and vitamin D supplementation (124).

In patients with early stage breast cancer under adjuvant chemotherapy, zoledronic acid $4 \mathrm{mg}$ every 3 months for 2 years was shown to prevent bone loss in a RCT in women who developed ovarian failure after adjuvant chemotherapy (125). Over a period of 5 years, in a study of 34 women (mean age 43 years), who were also treated with $4 \mathrm{mg}$ intravenous zoledronic acid every 3 months during 2 years, bone loss was prevented at the hip and significantly reduced at the spine compared to placebo-treated women, and BMD was maintained up to 3 years after bisphosphonate treatment was discontinued (126). Bone loss induced by ovarian suppression therapy (goserelin) and tamoxifen or anastrozole can also be prevented by zoledronic acid $4 \mathrm{mg}$ every 6 months for 3 years in premenopausal women with endocrine-sensitive early-stage breast cancer. Moreover, in this large study, disease-free survival was prolonged in patients receiving zoledronic acid (127).

\section{Pregnancy-associated osteoporosis. For PLAO} treatment, there are new data available from retrospective studies. In particular, a retrospective case-series of 12 patients diagnosed with PLAO at mean age of $31 \pm 5$ years and treated with alendronate or zoledronic acid $(\mathrm{n}=6)$, with a follow-up period of 6 months up to 48 months, confirmed a gain in BMD and a decrease of bone turnover markers in each patient (128). The largest retrospective, multicenter study, including 52 patients, with a mean of $3.8 \pm 2$ vertebral fractures, reported that patients without any treatment had an annual mean gain of LS BMD of $6.6 \%$ and $2.3 \%$ at the hip, whereas patients treated with bisphosphonates had an increase in LS BMD of $10.2 \%$ and $2.6 \%$ at the FN (129). Patients treated with teriparatide had an annual mean BMD gain of $14.9 \%$ at the LS and $5.6 \%$ at the FN. Approximately $19 \%$ had a new fracture during follow-up (36 months) regardless of treatment administered. Interestingly, the same magnitude of increase in LS BMD was reported in another retrospective study of 32 PLAO women with multiple fractures treated with teriparatide for 12 months, with greater BMD increases in the teriparatide group compared to controls $(15.5 \% \pm 6.6$ vs $7.5 \% \pm 7.1, P=0.02)(130)$.

Idiopathic osteoporosis. RCTs are missing with regard to the treatment of premenopausal idiopathic osteoporosis. Teriparatide has been used, as previously reviewed, in a small sample of women with this disorder (17). The latest study using teriparatide included analyses of bone biopsies and the expression of the IGF-1 receptor (IGF-1R) on circulating osteoblast progenitor (COP) among peripheral blood mononuclear cells (PBMCs) (131). In 11 premenopausal women treated with teriparatide for 24 months, a BMD increase of $2.9 \pm 5.7 \%$ at the spine and a $6.9 \pm 4.6 \%$ increase at the FN were reported (131). This study showed that the percentage COP cells and IGF-1R expression on COP cells reflected tissue level bone formation (131). Thus, the authors proposed that the amount of IGF-1R on COP cells may reflect IGF-1 resistance downstream from the IGF-1R in premenopausal idiopathic osteoporosis. This new study is in line with previous studies that suggested an IGF-1 resistance in premenopausal idiopathic osteoporosis (132).

\section{Possible Teratogenic Effects of Anti-Osteoporotic Drugs}

Treatment of premenopausal women should always take into consideration the potential teratogenic effects of the drug during pregnancy. Although a toxic effect in pregnant rats after exposure to bisphosphonates has been described (133), the majority of the literature regarding bisphosphonate use in humans does not report severe adverse fetal and maternal events (134). Nevertheless, a few reports regarding shortened gestational age, lower neonatal birth weight and transient hypocalcemia in the newborns and very rare cases of spontaneous abortions and congenital anomalies have been published (135137). These studies, however, do not include controls or the reasons for bisphosphonate treatment.

In 2018, data were published from the French Reference Centre of Teratogenic Agents which included women who received bisphosphonates in the 6 weeks before or during pregnancy and had systemic $(\mathrm{n}=23)$ or bone diseases $(n=13)(138)$. This paper reported the reasons for bisphosphonate treatment and included control groups. The most frequent cause for bisphosphonate treatment was a rheumatologic disease (for which also concomitant drugs were prescribed), and these patients were compared to women with the same diseases without bisphosphonate exposure. In patients exposed to bisphosphonates due to systemic diseases, therapeutic terminations of pregnancies were higher compared to controls $(4 / 23[17.4 \%]$ vs $1 / 92[1.1 \%], P=0.006)$. No difference in the rate of congenital malformations was reported, but the rate of neonatal complications was higher for cases than controls $(4 / 16$ [25.0\%] vs 4/64 [6.3\%] $P=0.027)$. Neonatal complications included cardiac arrhythmias $(\mathrm{n}=1)$, maternal-fetal infection $(\mathrm{n}=1)$, acute fetal distress $(\mathrm{n}=1)$, and polycythemia and thrombocytopenia $(\mathrm{n}=1)$. Considering women without 
any systemic disease who received bisphosphonates for primary nonmalignant bone diseases (bone disease group), the live birth rate was lower compared to healthy controls $(8 / 10[80 \%]$ vs $50 / 50[100 \%], P=0.025)$. No congenital malformations were reported in either group; however, fetopathological examinations were not performed. It might be possible that the complications reported were mainly due to the severity of the underlying diseases and other concomitant medication; however, a severity index for the diseases was not reported. The authors stated that the expected rate of spontaneous abortion is approximatively $12 \%$ in the general population in France; thus, using the healthy control group as a comparison for the "bone disease" group without spontaneous abortions might not be appropriate. Further studies are needed to clarify this issue. As a measure of safety, it has been proposed that bisphosphonate treatment should not be initiated if a woman is planning a pregnancy in the next 12 months (16).

There are no human case reports on the fetal effects of teriparatide or denosumab in pregnant women. In cynomolgus monkeys, who were exposed to denosumab in utero, the following persistent congenital defects were reported: dental dysplasia, decreased bone length, reduced cortical thickness, and decreased peak load and ultimate strength at the femur diaphysis, while others bone features that resembled an osteoporotic phenotype appeared partially reversible (139).

Hence, both denosumab and teriparatide are contraindicated in pregnant women; this recommendation is based on the lack of studies in pregnant women.

\section{Conclusions}

Underlying diseases are common among premenopausal women with osteoporosis. The diagnosis of osteoporosis in premenopausal women requires not only the presence of low BMD but also evidence of bone fragility, which reflects an abnormal bone microarchitecture. In contrast to postmenopausal women, however, bone turnover is not necessarily elevated in premenopausal osteoporosis, at least not when estrogen deficiency is absent. In the rare cases of idiopathic osteoporosis, new evidence from HR-pQCT and genetic evaluations suggest that the primary deficit is in the osteoblast function, but the exact mechanisms remains unknown. Identifying premenopausal women at risk of fracture remains challenging, and further HR-pQCT studies may contribute to understand the importance of bone microstructural alterations in this population, although the clinical use of this technology remains uncertain. Moreover, we need additional research to establish normative databases for premenopausal women, so that in the future, HR-pQCT will be more useful clinically. Meanwhile, DXA with vertebral fracture assessment, common clinical risk factors, and disease- and drug-related risk factors (in case of secondary osteoporosis) must all be taken into account to properly assess fracture risk in these women, as recently illustrated in diabetes (47).

The treatment of underlying causes of secondary osteoporosis is beneficial not only with regards to BMD but also to bone microstructure. In case treatment of the underlying cause is not successful and/or in presence of severe osteoporosis, antiresorptive and bone-forming drugs can be used as in postmenopausal osteoporosis. Further RCTs with fracture reduction as a primary outcome are needed to better tailor treatment to patients at high risk of fracture. Although some new data on bisphosphonate safety in women at childbearing potential are now available, more robust evidence is needed as well as data on denosumab and bone-forming drugs like teriparatide, abaloparatide, and romosozumab in humans.

\section{Acknowledgments}

Financial Support: The paper received no fund.

\section{Additional Information}

Correspondence and Reprint Requests: Jessica Pepe, Department of Clinical, Internal, Anesthesiology and Cardiovascular Sciences, "Sapienza” University of Rome, Viale del Policlinico, Rome 00161, Italy. jessica.pepe@uniroma1.it.

Disclosure summary: JP has nothing to disclose. BL received research funding from Amgen and Novo Nordisk and served on the advisory board of and gave lectures for Eli Lilly, UCB, and Amgen. ET received research funding from MSD; honoraria for lectures from Amgen, UCB, Shire, and Kyowa Kirin; and educational grants from Shire and UCB. JJB received research funding from UCB and honoraria for consultancy/lectures from Sandoz, Takeda, and UCB. CM received research funding from Amgen and Roche Diagnostics and served on the advisory board of and provided lectures for Amgen, Mylan-MEDA, Gedeon Richter, and UCB. EVM served as a consultant/advisor/speaker for AgNovos, Amgen, AstraZeneca, Consilient Healthcare, Fresenius Kabi, GSK, Hologic, Internis, Lilly, Merck, Novartis, Pfizer, Roche, SanofiAventis, and UCB. Research support includes the previously listed support plus Versus Arthritis, I3 Innovus, MRC, IOF, and Unilever. BOP received research funding from IDS and ViennaLab and educational grants from Gedeon Richter, IDS, Shire, and Kyowa Kirin. PH serviced on the advisory board, provided lectures, and received research funding from 
Amgen, Dr. Kade/Besins, Eli Lilly, Gedeon Richter, Hexal, Mylan, Novartis, and UCB. MCZ has received honoraria in the past for lectures or advice from Alexion, Amgen, Eli Lilly, Kyowa Kirin, Shire, and UCB. SF received research funding from AMGEN, Agnovos, Labatec, Alexion, Consulting for AMGEN, UCB, Radius, Agnovos, Galapagos, and Spirig. AP has nothing to disclose.

Data Availability: All data generated or analyzed during this study are included in this published article or in the data repositories listed in References.

\section{References}

1. Ferrari S, Bianchi ML, Eisman JA, Foldes AJ, Adami S, Wahl DA, Stepan JJ, de Vernejoul MC, Kaufman JM; IOF Committee of Scientific Advisors Working Group on Osteoporosis Pathophysiology.

2. Khan AA, Syed Z. Bone densitometry in premenopausal women: synthesis and review. J Clin Densitom. 2004;7(1):85-92.

3. Liu JM, Zhao HY, Ning G, Chen Y, Zhang LZ, Sun LH, Zhao YJ, $\mathrm{Xu}$ MY, Chen JL. IGF-1 as an early marker for low bone mass or osteoporosis in premenopausal and postmenopausal women. $J$ Bone Miner Metab. 2008;26(2):159-164.

4. Cramarossa G, Urowitz MB, Su J, Gladman D, Touma Z. Prevalence and associated factors of low bone mass in adults with systemic lupus erythematosus. Lupus. 2017;26(4):365-372.

5. Sharma M, Dhakad U, Wakhlu A, Bhadu D, Dutta D, Das SK. Lean mass and disease activity are the best predictors of bone mineral loss in the premenopausal women with rheumatoid arthritis. Indian J Endocrinol Metab. 2018;22(2):236-243.

6. Rahaman SH, Jyotsna VP, Kandasamy D, Shreenivas V, Gupta N, Tandon N. Bone health in patients with Cushing's syndrome. Indian J Endocrinol Metab. 2018;22(6):766-769.

7. Dutta D, Garga UC, Gadpayle AK, Bansal R, Anand A, Gaurav K, Sharma LK, Sharma N. Occurrence \& predictors of osteoporosis \& impact of body composition alterations on bone mineral health in asymptomatic pre-menopausal women with HIV infection. Indian J Med Res. 2018;147(5):484-495.

8. Cairoli E, Eller-Vainicher C, Morlacchi LC, Tarsia P, Rossetti V, Pappalettera M, Arosio M, Chiodini I, Blasi F. Bone involvement in young adults with cystic fibrosis awaiting lung transplantation for end-stage respiratory failure. Osteoporos Int. 2019;30(6):1255-1263.

9. Hosmer WD, Genant HK, Browner WS. Fractures before menopause: a red flag for physicians. Osteoporos Int. 2002;13(4):337-341.

10. Cohen A, Shane E. Evaluation and management of the premenopausal woman with low BMD. Curr Osteoporos Rep. 2013;11(4):276-285.

11. Wu F, Mason B, Horne A, Ames R, Clearwater J, Liu M, Evans MC, Gamble GD, Reid IR Fractures between the ages of 20 and 50 years increase women's risk of subsequent fractures. Arch Intern Med. 2002;162(1):33-36.

12. Gourlay ML, Brown SA. Clinical considerations in premenopausal osteoporosis. Arch Intern Med. 2004;164(6):603-614.

13. Leib ES. Treatment of low bone mass in premenopausal women: when may it be appropriate? Curr Osteoporos Rep. 2005;3(1):13-18.

14. McLendon AN, Woodis CB. A review of osteoporosis management in younger premenopausal women. Womens Health (Lond). 2014;10(1):59-77.

15. Abraham A, Cohen A, Shane E. Premenopausal bone health: osteoporosis in premenopausal women. Clin Obstet Gynecol. 2013;56(4):722-729.
16. Langdahl BL. Osteoporosis in premenopausal women. Curr Opin Rheumatol. 2017;29(4):410-415.

17. Cohen A. Premenopausal Osteoporosis. Endocrinol Metab Clin North Am. 2017;46(1):117-133.

18. Gordon CM, Zemel BS, Wren TA, Leonard MB, Bachrach LK, Rauch F, Gilsanz V, Rosen CJ, Winer KK. The determinants of peak bone mass. J Pediatr. 2017;180:261-269.

19. Pepe J, Biver E, Bonnet N, Herrmann FR, Rizzoli R, Chevalley T, Ferrari SL. Within- and across-sex inheritance of bone microarchitecture. J Clin Endocrinol Metab. 2017;102(1):40-45.

20. Harvey N, Dennison E, Cooper C. Osteoporosis: a lifecourse approach. J Bone Miner Res. 2014;29(9):1917-1925.

21. Chew CK, Clarke BL. Causes of low peak bone mass in women. Maturitas. 2018;111:61-68.

22. Kim S, Baker BS, Sharma-Ghimire P, Bemben DA, Bemben MG. Association between bone-specific physical activity scores and pQCT-derived measures of bone strength and geometry in healthy young and middle-aged premenopausal women. Arch Osteoporos. 2018;13(1):83.

23. Khawaja A, Sabbagh P, Prioux J, Zunquin G, Baquet G, Maalouf G, El Hage R. Does muscular power predict bone mineral density in young adults? J Clin Densitom. 2019;22(3):311-320.

24. Greenway KG, Walkley JW, Rich PA. Impact exercise and bone density in premenopausal women with below average bone density for age. Eur J Appl Physiol. 2015;115(11):2457-2469.

25. Sipilä S, Törmäkangas T, Sillanpää E, Aukee P, Kujala UM, Kovanen V, Laakkonen EK Muscle and bone mass in middleaged women: role of menopausal status and physical activity. J Cachexia Sarcopenia Muscle. 2020 Feb 3. doi: 10.1002/ jcsm.12547. [Epub ahead of print]

26. Hammoud E, Toumi H, Jacob C, Pinti A, Lespessailles E, El Hage R. Influence of sarcopenia on bone health parameters in a group of eumenorrheic obese premenopausal women. $J$ Bone Miner Metab. 2020;38(3):385-391.

27. Luo Y, Jiang K, He M. Association between grip strength and bone mineral density in general US population of NHANES 2013-2014. Arch Osteoporos. 2020;15(1):47.

28. Goshtasebi A, Berger C, Barr SI, Kovacs CS, Towheed T, Davison KS, Prior JC. Adult premenopausal bone health related to reproductive characteristics-population-based data from the Canadian multicentre osteoporosis study (CaMos). Int J Environ Res Public Health. 2018;15(5):1023.

29. Chevalley T, Bonjour JP, Ferrari S, Rizzoli R. Pubertal timing and body mass index gain from birth to maturity in relation with femoral neck BMD and distal tibia microstructure in healthy female subjects. Osteoporos Int. 2011;22(10):2689.-2698.

30. Herring SA, Ben Kibler W, Putukian M. Female athlete issues for the team physician: a consensus statement-2017 update. Current Sports Medicine Reports. 2018;17(5):163-171.

31. Goshtasebi A, Subotic Brajic T, Scholes D, Beres Lederer Goldberg T, Berenson A, Prior JC. Adolescent use of combined hormonal contraception and peak bone mineral density accrual: a metaanalysis of international prospective controlled studies. Clin Endocrinol (Oxf). 2019;90(4):517-524.

32. Dombrowski S, Jacob L, Hadji P, Kostev K. Oral contraceptive use and fracture risk-a retrospective study of 12,970 women in the UK. Osteoporos Int. 2017;28(8):2349-2355.

33. Kyvernitakis I, Kostev K, Nassour T, Thomasius F, Hadji P. The impact of depot medroxyprogesterone acetate on fracture risk: a case-control study from the UK. Osteoporos Int. 2017;28(1):291-297.

34. Weaver CM, Gordon CM, Janz KF, Kalkwarf HJ, Lappe JM, Lewis R, O'Karma M, Wallace TC, Zemel BS. The National Osteoporosis Foundation's position statement on peak bone mass development and lifestyle factors: a systematic review and implementation recommendations. Osteoporos Int. 2016;27(4): 1281-1386. 
35. Chevalley T, Bonjour JP, Audet MC, Merminod F, van Rietbergen B, Rizzoli R, Ferrari S. Prepubertal impact of protein intake and physical activity on weight-bearing peak bone mass and strength in males. J Clin Endocrinol Metab. 2017;102(1):157-166.

36. Bonjour JP, Chevalley T, Rizzoli R, Ferrari S. Gene-environment interactions in the skeletal response to nutrition and exercise during growth. Med Sport Sci. 2007;51:64-80.

37. Ferrari SL, Rizzoli R, Slosman DO, Bonjour JP. Do dietary calcium and age explain the controversy surrounding the relationship between bone mineral density and vitamin $\mathrm{D}$ receptor gene polymorphisms? J Bone Miner Res. 1998;13(3):363-370.

38. Ferrari S, Bonjour JP, Rizzoli R. The vitamin D receptor gene and calcium metabolism. Trends Endocrinol Metab. 1998;9(7):259-265.

39. Yang Y, Wu F, Winzenberg T, Jones G. The association of vitamin $\mathrm{D}$ in youth and early adulthood with bone mineral density and microarchitecture in early adulthood. Calcif Tissue Int. 2019;104(6):605-612.

40. Bates B, Lennox A, Prentice A, Page P, Nicholson S, Swan G. (2014) National diet and nutrition survey: results from years 1, 2, 3 and 4 (combined) of the Rolling Programme (2008/ 2009-2011/2012). London, UK: Public Health England. Available at https://www.gov.uk/government/statistics/nationaldiet-andnutrition-survey-results-from-years-1-to-4-combined-oftherolling-programme-for-2008-and-2009-to-2011-and-2012.

41. Hough FS, Pierroz DD, Cooper C, Ferrari SL; IOF CSA Bone and Diabetes Working Group. Mechanisms In Endocrinology: Mechanisms and evaluation of bone fragility in type 1 diabetes mellitus. Eur J Endocrinol. 2016;174(4):R127-R138.

42. Lewiecki EM, Gordon CM, Baim S, Binkley N, Bilezikian JP, Kendler DL, Hans DB, Silverman S, Bishop NJ, Leonard MB, Bianchi ML, Kalkwarf HJ, Langman CB, Plotkin H, Rauch F, Zemel BS. Special report on the 2007 adult and pediatric Position Development Conferences of the International Society for Clinical Densitometry. Osteoporos Int. 2008;19(10):1369-1378.

43. Cohen A, Lang TF, McMahon DJ, Liu XS, Guo XE, Zhang C, Stein EM, Dempster DW, Young P, Saeed I, Lappe JM, Recker RR, Shane E. Central QCT reveals lower volumetric BMD and stiffness in premenopausal women with idiopathic osteoporosis, regardless of fracture history. J Clin Endocrinol Metab. 2012;97(11):4244-4252.

44. Kanis JA, Cooper C, Rizzoli R, Reginster JY; Scientific Advisory Board of the European Society for Clinical and Economic Aspects of Osteoporosis and Osteoarthritis (ESCEO) and the Committees of Scientific Advisors and National Societies of the International Osteoporosis Foundation (IOF). Executive summary of the European guidance for the diagnosis and management of osteoporosis in postmenopausal women. Calcif Tissue Int. 2019;104(3):235-238.

45. Kyvernitakis I, Reuter TC, Hellmeyer L, Hars O, Hadji P. Subsequent fracture risk of women with pregnancy and lactationassociated osteoporosis after a median of 6 years of follow-up. Osteoporos Int. 2018;29(1):135-142.

46. Fouda MA, Khan AA, Sultan MS, Rios LP, McAssey K, Armstrong D. Evaluation and management of skeletal health in celiac disease: position statement. Can J Gastroenterol. 2012;26(11):819-829.

47. Ferrari SL, Abrahamsen B, Napoli N, Akesson K, Chandran M, Eastell R, El-Hajj Fuleihan G, Josse R, Kendler DL, Kraenzlin M, Suzuki A, Pierroz DD, Schwartz AV, Leslie WD; Bone and Diabetes Working Group of IOF. Diagnosis and management of bone fragility in diabetes: an emerging challenge. Osteoporos Int. 2018;29(12):2585-2596.

48. Ting BL, Walley KC, Travison TG, Rozental TD. Elevated bone turnover markers are associated with distal radius fractures in premenopausal women. J Hand Surg Am. 2017;42(2):71-77.

49. Gutierrez-Buey G, Restituto P, Botella S, Monreal I, Colina I, Rodríguez-Fraile M, Calleja A, Varo N. Trabecular bone score and bone remodelling markers identify perimenopausal women at high risk of bone loss. Clin Endocrinol (Oxf). 2019;91(3):391-399.

50. Shieh A, Han W, Ishii S, Greendale GA, Crandall CJ, Karlamangla AS. Quantifying the balance between total bone formation and total bone resorption: an index of net bone formation. J Clin Endocrinol Metab. 2016;101(7):2802-2809.

51. Rozental TD, Johannesdottir F, Kempland KC, Bouxsein ML. Characterization of trabecular bone microstructure in premenopausal women with distal radius fractures. Osteoporos Int. 2018;29(2):409-419.

52. Khosla S, Lufkin EG, Hodgson SF, Fitzpatrick LA, Melton LJ $3^{\text {rd }}$. Epidemiology and clinical features of osteoporosis in young individuals. Bone. 1994;15(5):551-555.

53. Moreira Kulak CA, Schussheim DH, McMahon DJ, Kurland E, Silverberg SJ, Siris ES, Bilezikian JP, Shane E. Osteoporosis and low bone mass in premenopausal and perimenopausal women. Endocr Pract. 2000;6(4):296-304.

54. Cohen A, Fleischer J, Freeby MJ, McMahon DJ, Irani D, Shane E. Clinical characteristics and medication use among premenopausal women with osteoporosis and low BMD: the experience of an osteoporosis referral center. $J$ Womens Health (Larchmt). 2009;18(1):79-84.

55. Mori Y, Baba K, Kogure A, Izumiyama T, Matsuda M, Mori N, Ishii T, Itoi E. Assessment of the risk of low bone mineral density in premenopausal Japanese female patients with systemic lupus erythematosus. J Orthop. 2018;15(1):89-93.

56. Tedeschi SK, Kim SC, Guan H, Grossman JM, Costenbader KH. Comparative fracture risks among united states medicaid enrollees with and those without systemic lupus erythematosus. Arthritis Rheumatol. 2019;71(7):1141-1146.

57. Castellano E, Attanasio R, Boriano A, Pellegrino M, Garino F, Gianotti L, Borretta G. Sex difference in the clinical presentation of primary hyperparathyroidism: influence of menopausal status. $J$ Clin Endocrinol Metab. 2017;102(11):4148-4152.

58. Thong EP, Herath M, Weber DR, Ranasinha S, Ebeling PR, Milat F, Teede H. Fracture risk in young and middle-aged adults with type 1 diabetes mellitus: a systematic review and metaanalysis. Clin Endocrinol (Oxf). 2018;89(3):314-323.

59. Ganji R, Moghbeli M, Sadeghi R, Bayat G, Ganji A. Prevalence of osteoporosis and osteopenia in men and premenopausal women with celiac disease: a systematic review. Nutr J. 2019;18(1):9.

60. Pepe J, Zawadynski S, Herrmann FR, Juillerat P, Michetti P, Ferrari-Lacraz S, Belli D, Ratib O, Rizzoli R, Chevalley C, Ferrari SL. Structural basis of bone fragility in young subjects with inflammatory bowel disease: a high resolution pQCT study of the SWISS IBD cohort (SIBDC). Inflamm Bowel Dis. 2017;23:1410-1417.

61. Frølich J, Hansen S, Winkler LA, Andresen AK, Hermann AP, Støving RK. The role of body weight on bone in anorexia nervosa: a HR-pQCT study. Calcif Tissue Int. 2017;101(1):24-33.

62. Robinson CA, Hofer M, Benden C, Schmid C. Evaluation of bone disease in patients with cystic fibrosis and end-stage lung disease. J Bras Pneumol. 2019;45(1):e20170280.

63. Osella G, Priola AM, Priola SM, Piga A, Longo F, Ventura M, Bentivegna G, Angeli A, Veltri A, Terzolo M. Dual-energy X-ray absorptiometry predictors of vertebral deformities in betathalassemia major. J Clin Densitom. 2018;21(4):507-516.

64. Tuchendler D, Bolanowski M. Assessment of bone metabolism in premenopausal females with hyperthyroidism and hypothyroidism. Endokrynol Pol. 2013;64(1):40-44.

65. Schneider R, Schneider M, Reiners C, Schneider P. Effects of levothyroxine on bone mineral density, muscle force, and bone turnover markers: a cohort study. J Clin Endocrinol Metab. 2012;97(11):3926-3934.

66. Wang MT, Yao SH, Wong P, Trinh A, Ebeling PR, Tran T, Milat F, Mutalima N. Hip fractures in young adults: a retrospective cross-sectional study of characteristics, injury mechanism, 
risk factors, complications and follow-up. Arch Osteoporos. 2017;12(1):46.

67. Stagi S, Iurato C, Lapi E, Cavalli L, Brandi ML, de Martino M. Bone status in genetic syndromes: a review. Hormones (Athens). 2015;14(1):19-31.

68. Mornet E. Hypophosphatasia. Metabolism. 2018;82:142-155.

69. Papadopoulos I, Bountouvi E, Attilakos A, Gole E, Dinopoulos A, Peppa M, Nikolaidou P, Papadopoulou A. Osteoporosispseudoglioma syndrome: clinical, genetic, and treatment-response study of 10 new cases in Greece. Eur J Pediatr. 2019;178(3):323-329.

70. Solmi M, Veronese N, Correll CU, Favaro A, Santonastaso P, Caregaro L, Vancampfort D, Luchini C, De Hert M, Stubbs B. Bone mineral density, osteoporosis, and fractures among people with eating disorders: a systematic review and meta-analysis. Acta Psychiatr Scand. 2016;133(5):341-351.

71. Schorr M, Thomas JJ, Eddy KT, Dichtel LE, Lawson EA, Meenaghan E, Lederfine Paskal M, Fazeli PK, Faje AT, Misra M, Klibanski A, Miller KK. Bone density, body composition, and psychopathology of anorexia nervosa spectrum disorders in DSM-IV vs DSM-5. Int J Eat Disord. 2017;50(4):343-351.

72. Tamaki J, Iki M, Sato Y, Kajita E, Kagamimori S, Kagawa Y, Yoneshima H. Smoking among premenopausal women is associated with increased risk of low bone status: the JPOS study. $J$ Bone Miner Metab. 2010;28(3):320-327.

73. Ho-Pham LT, Nguyen ND, Nguyen TV. Effect of vegetarian diets on bone mineral density: a Bayesian meta-analysis. Am J Clin Nutr. 2009;90(4):943-950.

74. Xie L, Wang B, Cui X, Tang Q, Cai W, Shen X. Young adult vegetarians in Shanghai have comparable bone health to omnivores despite lower serum $25(\mathrm{OH})$ vitamin $\mathrm{D}$ in vegans: a cross-sectional study. Asia Pac J Clin Nutr. 2019;28(2):383-388.

75. Lips P, Cashman KD, Lamberg-Allardt C, Bischoff-Ferrari HA, Obermayer-Pietsch BR, Bianchi M, Stepan J, El-Hajj Fuleihan G, Bouillon R. Management of endocrine disease: current vitamin D status in European and Middle East countries and strategies to prevent vitamin D deficiency; a position statement of the European Calcified Tissue Society. Eur J Endocrinol. 2019;180(4):23-54.

76. Ferede A, Lemessa F, Tafa M, Sisay S. The prevalence of malnutrition and its associated risk factors among women of reproductive age in Ziway Dugda district, Arsi Zone, Oromia Regional State, Ethiopia. Public Health. 2017;152:1-8.

77. Kyvernitakis I, Kostev K, Hadji P. The tamoxifen paradoxinfluence of adjuvant tamoxifen on fracture risk in pre- and postmenopausal women with breast cancer. Osteoporos Int. 2018;29(11):2557-2564.

78. Stumpf U, Kostev K, Kyvernitakis J, Böcker W, Hadji P. Incidence of fractures in young women with breast cancer: a retrospective cohort study. J Bone Oncol. 2019;18:100254.

79. Francis PA, Pagani O, Fleming GF, Walley BA, Colleoni M, Lang I, Gomez HL, Tondini C, Ciruelos E, Burstein HJ, Bonnefoi HR, Bellet M, Martino S, Geyer CE Jr, Goetz MP, Stearns V, Pinotti G, Puglisi F, Spazzapan S, Climent MA, Pavesi L, Ruhstaller T, Davidson NE, Coleman R, Debled M, Buchholz S, Ingle JN, Winer EP, Maibach R, Rabaglio-Poretti M, Ruepp B, Di Leo A, Coates AS, Gelber RD, Goldhirsch A, Regan MM; SOFT and TEXT Investigators and the International Breast Cancer Study Group. Tailoring adjuvant endocrine therapy for premenopausal breast cancer. N Engl J Med. 2018;379(2):122-137.

80. Ramchand SK, Seeman E, Wang XF, Ghasem-Zadeh A, Francis PA, Ponnusamy EJ, Bardin MS, Bui M, Zebaze R, Zajac JD, Grossmann M. Premenopausal women with early breast cancer treated with estradiol suppression have severely deteriorated bone microstructure. Bone. 2017;103:131-135.

81. Taylor HS, Giudice LC, Lessey BA, Abrao MS, Kotarski J, Archer DF, Diamond MP, Surrey E, Johnson NP, Watts NB, Gallagher JC, Simon JA, Carr BR, Dmowski WP, Leyland N, Rowan JP, Duan WR, Ng J, Schwefel B, Thomas JW, Jain RI, Chwalisz K. Treatment of endometriosis-associated pain with elagolix, an oral GnRH antagonist. $N$ Engl J Med. 2017;377(1):28-40.

82. Surrey E, Taylor HS, Giudice L, Lessey BA, Abrao MS, Archer DF, Diamond MP, Johnson NP, Watts NB, Gallagher JC, Simon JA, Carr BR, Dmowski WP, Leyland N, Singh SS, Rechberger T, Agarwal SK, Duan WR, Schwefel B, Thomas JW, Peloso PM, $\mathrm{Ng}$ J, Soliman AM, Chwalisz K. Long-term outcomes of elagolix in women with endometriosis: results from two extension studies. Obstet Gynecol. 2018;132(1):147-160.

83. Schlaff WD, Ackerman RT, Al-Hendy A, Archer DF, Barnhart KT, Bradley LD, Carr BR, Feinberg EC, Hurtado SM, Kim J, Liu R, Mabey RG Jr, Owens CD, Poindexter A, Puscheck EE, RodriguezGinorio H, Simon JA, Soliman AM, Stewart EA, Watts NB, Muneyyirci-Delale O. Elagolix for heavy menstrual bleeding in women with uterine fibroids. N Engl J Med. 2020;382(4):328-340.

84. Kendler DL, Body JJ, Brandi ML, Broady R, Cannata-Andia J, Cannata-Ortiz MJ, El Maghraoui A, Guglielmi G, Hadji P, Pierroz DD, de Villiers TJ, Rizzoli R, Ebeling PR; International Osteoporosis Foundation Committee of Scientific Advisors Working Group on Cancer and Bone Disease. Bone management in hematologic stem cell transplant recipients. Osteoporos Int. 2018;29(12):2597-2610.

85. Buckley L, Humphrey MB. Glucocorticoid-induced osteoporosis. N Engl J Med. 2018;379(26):2547-2556.

86. Carli L, Tani C, Spera V, Vagelli R, Vagnani S, Mazzantini M, Di Munno O, Mosca M. Risk factors for osteoporosis and fragility fractures in patients with systemic lupus erythematosus. Lupus Sci Med. 2016;3(1):e000098.

87. Ostertag A, Cohen-Solal M, Audran M, Legrand E, Marty C, Chappard D, de Vernejoul MC. Vertebral fractures are associated with increased cortical porosity in iliac crest bone biopsy of men with idiopathic osteoporosis. Bone. 2009;44(3):413-417.

88. Rolvien T, Stürznickel J, Schmidt FN, Butscheidt S, Schmidt T, Busse B, Mundlos S, Schinke T, Kornak U, Amling M, Oheim R.Comparison of bone microarchitecture between adult osteogenesis imperfecta and early-onset osteoporosis. Calcif Tissue Int. 2018;103(5):512-521.

89. Collet C, Ostertag A, Ricquebourg M, Delecourt M, Tueur G, Isidor B, Guillot P, Schaefer E, Javier RM, Funck-Brentano T, Orcel P, Laplanche JL, Cohen-Solal M. Primary osteoporosis in young adults: genetic basis and identification of novel variants in causal genes. JBMR Plus. 2018;2(1):12-21.

90. Ferrari SL, Deutsch S, Baudoin C, Cohen-Solal M, Ostertag A, Antonarakis SE, Rizzoli R, de Vernejoul MC. LRP5 gene polymorphisms and idiopathic osteoporosis in men. Bone. 2005;37(6):770-775.

91. Hardcastle SA, Yahya F, Bhalla AK. Pregnancy-associated osteoporosis: a UK case series and literature review. Osteoporos Int. 2019;30(5):939-948.

92. Kovacs CS. Osteoporosis presenting in pregnancy, puerperium, and lactation. Curr Opin Endocrinol Diabetes Obes. 2014;21(6):468-475.

93. Hellmeyer L, Hahn B, Fischer C, Hars O, Boekhoff J, Maier J, Hadji P. Quantitative ultrasonometry during pregnancy and lactation: a longitudinal study. Osteoporos Int. 2015;26(3):1147-1154.

94. Cooke-Hubley S, Gao Z, Mugford G, Kaiser SM, Goltzman D, Leslie WD, Davison KS, Brown JP, Probyn L, Lentle B, Prior JC, Kovacs CS. Parity and lactation are not associated with incident fragility fractures or radiographic vertebral fractures over 16 years of follow-up: Canadian Multicentre Osteoporosis Study (CaMos). Arch Osteoporos. 2019;14(1):49.

95. Hadji P, Boekhoff J, Hahn M, Hellmeyer L, Hars O, Kyvernitakis I. Pregnancy-associated osteoporosis: a case-control study. Osteoporos Int. 2017;28(4):1393-1399.

96. Hadji P, Boekhoff J, Hahn M, Hellmeyer L, Hars O, Kyvernitakis I. Pregnancy-associated transient osteoporosis of the hip: results of a case-control study. Arch Osteoporos. 2017;12(1):11. 
97. Cohen A, Kamanda-Kosseh M, Dempster DW, Zhou $\mathrm{H}$, Müller R, Goff E, Colon I, Bucovsky M, Stubby J, Nickolas TL, Stein EM, Recker RR, Lappe JM, Shane E. Women with pregnancy and lactation-associated osteoporosis (PLO) have low bone remodeling rates at the tissue level. J Bone Miner Res. 2019;34(9):1552-1561.

98. Butscheidt S, Delsmann A, Rolvien T, Barvencik F, Al-Bughaili M, Mundlos S, Schinke T, Amling M, Kornak U, Oheim R. Mutational analysis uncovers monogenic bone disorders in women with pregnancy-associated osteoporosis: three novel mutations in LRP5, COL1A1, and COL1A2. Osteoporos Int. 2018;29(7):1643-1651.

99. Wu F, Wills K, Laslett LL, Riley MD, Oldenburg B, Jones G, Winzenberg T.Individualized fracture risk feedback and long-term benefits after 10 years. Am J Prev Med. 2018;54(2):266-274.

100. Chan CY, Mohamed N, Ima-Nirwana S, Chin KY. A review of knowledge, belief and practice regarding osteoporosis among adolescents and young adults. Int J Environ Res Public Health. 2018;15(8):1727.

101. Arazi H, Samadpour M, Eghbali E. The effects of concurrent training (aerobic-resistance) and milk consumption on some markers of bone mineral density in women with osteoporosis. BMC Womens Health. 2018;18(1):202.

102. Tabatabai LS, Bloom J, Stewart S, Sellmeyer DE. A randomized controlled trial of exercise to prevent bone loss in premenopausal women with breast cancer. J Womens Health (Larchmt). 2019;28(1):87-92.

103. Marcinow ML, Randall Simpson JA, Whiting SJ, Jung ME, Buchholz AC. Young adults' perceptions of calcium intake and health: a qualitative study. Health Educ Behav. 2017;44(6):898-906.

104. Zareef TA, Jackson RT, Alkahtani AA. Vitamin D intake among premenopausal women living in Jeddah: food sources and relationship to demographic factors and bone health. J Nutr Metab. 2018;2018:8570986.

105. Caviezel D, Maissen S, Niess JH, Kiss C, Hruz P. High prevalence of vitamin D deficiency among patients with inflammatory bowel disease. Inflamm Intest Dis. 2018;2(4):200-210.

106. Vodopivec DM, Silva AM, Garcia-Banigan DC, Christakis I, Stewart A, Schwarz K, Hussey CS, Bassett R, Hu MI, Perrier ND. Gender differences in bone mineral density in patients with sporadic primary hyperparathyroidism. Endocrinol Diabetes Metab. 2018;1(4):e00037.

107. Maldonado-Pérez MB, Castro-Laria L, Caunedo-Álvarez A, Montoya-García MJ, Giner-García M, Argüelles-Arias F, Romero-Gómez M, Vázquez-Gámez MÁ. Does the antitumor necrosis factor- $\alpha$ therapy decrease the vertebral fractures occurrence in inflammatory bowel disease? J Clin Densitom. 2019;22(2):195-202.

108. Frei R, Fournier N, Zeitz J, Scharl M, Morell B, Greuter T, Schreiner P, Misselwitz B, Safroneeva E, Schoepfer AM, Vavricka SR, Rogler G, Biedermann L; Swiss IBD Cohort Study Group. Early initiation of anti-TNF is associated with favourable long-term outcome in crohn's disease: 10-year-follow-up data from the Swiss IBD Cohort Study. J Crohns Colitis. 2019;13(10):1292-1301.

109. Zanchetta MB, Longobardi V, Costa F, Longarini G, Mazure RM, Moreno ML, Vázquez H, Silveira F, Niveloni S, Smecuol E, de la Paz Temprano M, Massari F, Sugai E, González A, Mauriño EC, Bogado C, Zanchetta JR, Bai JC. Impaired bone microarchitecture improves after one year on gluten-free diet: a prospective longitudinal HRpQCT study in women with celiac disease. J Bone Miner Res. 2017;32(1):135-142.

110. Achamrah N, Coëffier $M$, Jésus $P$, Charles J, Rimbert A, Déchelotte P, Grigioni S. Bone mineral density after weight gain in 160 patients with anorexia nervosa. Front Nutr. 2017;4:46.

111. Shin K, Park SH, Park W, Baek HJ, Lee YJ, Kang SW, Choe JY, Yoo WH, Park YB, Song JS, Lee SG, Yoo B, Yoo DH, Song YW. Monthly oral ibandronate reduces bone loss in korean women with rheumatoid arthritis and osteopenia receiving long-term glucocorticoids: a 48-week double-blinded randomized placebocontrolled investigator-initiated trial. Clin Ther. 2017;39(2):268278.e2.

112. Kumar M, Rastogi A, Bhadada SK, Bhansali A, Vaiphei K, Kochhar R. Effect of zoledronic acid on bone mineral density in patients of celiac disease: a prospective, randomized, pilot study. Indian J Med Res. 2013;138(6):882-887.

113. Fazeli PK, Wang IS, Miller KK, Herzog DB, Misra M, Lee H, Finkelstein JS, Bouxsein ML, Klibanski A. Teriparatide increases bone formation and bone mineral density in adult women with anorexia nervosa. I Clin Endocrinol Metab. 2014;99(4):1322-1329.

114. Rozenberg S, Lanoy E, Bentata M, Viard JP, Valantin MA, Missy P, Darasteanu I, Roux C, Kolta S, Costagliola D; ANRS 120 Fosivir Study Group. Effect of alendronate on HIV-associated osteoporosis: a randomized, double-blind, placebo-controlled, 96-week trial (ANRS 120). AIDS Res Hum Retroviruses. 2012;28(9):972-980.

115. Bianchi ML, Colombo C, Assael BM, Dubini A, Lombardo M, Quattrucci S, Bella S, Collura M, Messore B, Raia V, Poli F, Bini R, Albanese CV, De Rose V, Costantini D, Romano G, Pustorino E, Magazzù G, Bertasi S, Lucidi V, Traverso G, Coruzzo A, Grzejdziak AD. Treatment of low bone density in young people with cystic fibrosis: a multicentre, prospective, open-label observational study of calcium and calcifediol followed by a randomised placebo-controlled trial of alendronate. Lancet Respir Med. 2013;1(5):377-385.

116. Conwell LS, Chang AB. Bisphosphonates for osteoporosis in people with cystic fibrosis. Cochrane Database Syst Rev. 2014;3:CD002010.

117. Bhardwaj A, Swe KM, Sinha NK, Osunkwo I. Treatment for osteoporosis in people with ß-thalassaemia. Cochrane Database Syst Rev. 2016;3:CD010429.

118. Yao L, Wang H, Dong W, Liu Z, Mao H. Efficacy and safety of bisphosphonates in management of low bone density in inflammatory bowel disease: a meta-analysis. Medicine (Baltimore). 2017;96(3):e5861.

119. Miller KK, Lee EE, Lawson EA, Misra M, Minihan J, Grinspoon SK, Gleysteen S, Mickley D, Herzog D, Klibanski A. Determinants of skeletal loss and recovery in anorexia nervosa. $J$ Clin Endocrinol Metab. 2006;91(8):2931-2937.

120. Robinson L, Aldridge V, Clark EM, Misra M, Micali N. Pharmacological treatment options for low bone mineral density and secondary osteoporosis in anorexia nervosa: a systematic review of the literature. J Psychosom Res. 2017;98:87-97.

121. Miller KK, Meenaghan E, Lawson EA, Misra M, Gleysteen S, Schoenfeld D, Herzog D, Klibanski A. Effects of risedronate and low-dose transdermal testosterone on bone mineral density in women with anorexia nervosa: a randomized, placebocontrolled study. J Clin Endocrinol Metab. 2011;96(7): 2081-2088.

122. Lekamwasam S, Adachi JD, Agnusdei D, Bilezikian J, Boonen S, Borgström F, Cooper C, Diez Perez A, Eastell R, Hofbauer LC, Kanis JA, Langdahl BL, Lesnyak O, Lorenc R, McCloskey E, Messina OD, Napoli N, Obermayer-Pietsch B, Ralston SH, Sambrook PN, Silverman S, Sosa M, Stepan J, Suppan G, Wahl DA, Compston JE; Joint IOF-ECTS GIO Guidelines Working Group. A framework for the development of guidelines for the management of glucocorticoid-induced osteoporosis. Osteoporos Int. 2012;23(9):2257-2276.

123. Buckley L, Guyatt G, Fink HA, Cannon M, Grossman J, Hansen KE, Humphrey MB, Lane NE, Magrey M, Miller M, Morrison L, Rao M, Byun Robinson A, Saha S, Wolver S, Bannuru RR, Vaysbrot E, Osani M, Turgunbaev M, Miller AS, McAlindon T. 2017 American College of Rheumatology Guideline for the prevention and treatment of glucocorticoidinduced osteoporosis. Arthritis Care Res (Hoboken). 2017;69(8):1095-1110. 
124. Hadji P, Gnant M, Body JJ, Bundred NJ, Brufsky A, Coleman RE, Guise TA, Lipton A, Aapro MS. Cancer treatment-induced bone loss in premenopausal women: a need for therapeutic intervention? Cancer Treat Rev. 2012;38(6):798-806.

125. Shapiro CL, Halabi S, Hars V, Archer L, Weckstein D, Kirshner J, Sikov W, Winer E, Burstein HJ, Hudis C, Isaacs C, Schilsky R, Paskett E. Zoledronic acid preserves bone mineral density in premenopausal women who develop ovarian failure due to adjuvant chemotherapy: final results from CALGB trial 79809. Eur J Cancer. 2011;47(5):683-689.

126. Kyvernitakis I, Kann PH, Thomasius F, Hars O, Hadji P. Prevention of breast cancer treatment-induced bone loss in premenopausal women treated with zoledronic acid: Final 5-year results from the randomized, double-blind, placebo-controlled ProBONE II trial. Bone. 2018;114:109-115.

127. Gnant M, Mlineritsch B, Stoeger H, Luschin-Ebengreuth G, Heck D, Menzel C, Jakesz R, Seifert M, Hubalek M, Pristauz G, Bauernhofer T, Eidtmann H, Eiermann W, Steger G, Kwasny W, Dubsky P, Hochreiner G, Forsthuber EP, Fesl C, Greil R; Austrian Breast and Colorectal Cancer Study Group. Adjuvant endocrine therapy plus zoledronic acid in premenopausal women with early-stage breast cancer: 62-month follow-up from the ABCSG12 randomised trial. Lancet Oncol. 2011;12(7):631-641.

128. Li LJ, Zhang J, Gao P, Lv F, Song YW, Chang XY, Zhao DC, Wang O, Jiang Y, Xing XP, Xia WB, Li M. Clinical characteristics and bisphosphonates treatment of rare pregnancyand lactation-associated osteoporosis. Clin Rheumatol. 2018;37(11):3141-3150.

129. Laroche M, Talibart M, Cormier C, Roux C, Guggenbuhl P, Degboe Y. Pregnancy-related fractures: a retrospective study of a French cohort of 52 patients and review of the literature. Osteoporos Int. 2017;28(11):3135-3142.

130. Hong N, Kim JE, Lee SJ, Kim SH, Rhee Y. Changes in bone mineral density and bone turnover markers during treatment with teriparatide in pregnancy- and lactation-associated osteoporosis. Clin Endocrinol (Oxf). 2018;88(5):652-658.

131. Cohen A, Kousteni S, Bisikirska B, Shah JG, Manavalan JS, Recker RR, Lappe J, Dempster DW, Zhou H, McMahon DJ,
Bucovsky M, Kamanda-Kosseh M, Stubby J, Shane E. IGF-1 receptor expression on circulating osteoblast progenitor cells predicts tissue-based bone formation rate and response to teriparatide in premenopausal women with idiopathic osteoporosis. J Bone Miner Res. 2017;32(6):1267-1273.

132. Cohen A, Dempster DW, Recker RR, Stein EM, Lappe JM, Zhou H, Wirth AJ, van Lenthe GH, Kohler T, Zwahlen A, Müller R, Rosen CJ, Cremers S, Nickolas TL, McMahon DJ, Rogers H, Staron RB, LeMaster J, Shane E. Abnormal bone microarchitecture and evidence of osteoblast dysfunction in premenopausal women with idiopathic osteoporosis. I Clin Endocrinol Metab. 2011;96(10):3095-3105.

133. Minsker DH, Manson JM, Peter CP. Effects of the bisphosphonate, alendronate, on parturition in the rat. Toxicol Appl Pharmacol. 1993;121(2):217-223.

134. Machairiotis N, Ntali G, Kouroutou P, Michala L. Clinical evidence of the effect of bisphosphonates on pregnancy and the infant. Horm Mol Biol Clin Investig. 2019;40(2).

135. Levy S, Fayez I, Taguchi N, Han JY, Aiello J, Matsui D, Moretti M, Koren G, Ito S. Pregnancy outcome following in utero exposure to bisphosphonates. Bone. 2009;44(3):428-430.

136. Ornoy A, Wajnberg R, Diav-Citrin O. The outcome of pregnancy following pre-pregnancy or early pregnancy alendronate treatment. Reprod Toxicol. 2006;22(4):578-579.

137. Stathopoulos IP, Liakou CG, Katsalira A, Trovas G, Lyritis GG, Papaioannou NA, Tournis S. The use of bisphosphonates in women prior to or during pregnancy and lactation. Hormones (Athens). 2011;10(4):280-291.

138. Sokal A,ElefantE,Leturcq T,BeghinD, MarietteX,Seror R.Pregnancy and newborn outcomes after exposure to bisphosphonates: a casecontrol study. Osteoporos Int. 2019;30(1):221-229.

139. Boyce RW, Varela A, Chouinard L, Bussiere JL, Chellman GJ, Ominsky MS, Pyrah IT. Infant cynomolgus monkeys exposed to denosumab in utero exhibit an osteoclast-poor osteopetroticlike skeletal phenotype at birth and in the early postnatal period. Bone. 2014;64:314-325. 